\title{
Influence of Lactic Acid Bacterium Strains on Changes in Quality, Functional Compounds and Volatile Compounds of Mango Juice from Different Cultivars during Fermentation
}

\author{
Nobahle P. Cele ${ }^{1}$, Stephen A. Akinola ${ }^{1}$, Vimbainashe E. Manhivi ${ }^{1} \mathbb{D}$, Tinotenda Shoko ${ }^{1}$, Fabienne Remize ${ }^{2,3}{ }^{\mathbb{D}}$ \\ and Dharini Sivakumar $1, *$ D \\ 1 Phytochemical Food Network Department of Crop Sciences, Tshwane University of Technology, \\ Pretoria 0001, South Africa; zamandoccy24@gmail.com (N.P.C.); AkinolaSA@tut.ac.za (S.A.A.); \\ ManhiviVE@tut.ac.za (V.E.M.); ShokoT@tut.ac.za (T.S.) \\ 2 INRAE, Institut Agro Montpellier, SupAgro et, Université de Montpellier, F-34000 Montpellier, France; \\ fabienne.remize@univ-reunion.fr \\ 3 Qualisud, Chemin de l'lrat, Université La Réunion, F-97410 Saint Pierre, France \\ * Correspondence: SivakuamarD@tut.ac.za
}

check for

updates

Citation: Cele, N.P.; Akinola, S.A.; Manhivi, V.E.; Shoko, T.; Remize, F.; Sivakumar, D. Influence of Lactic Acid Bacterium Strains on Changes in Quality, Functional Compounds and Volatile Compounds of Mango Juice from Different Cultivars during Fermentation. Foods 2022, 11, 682. https://doi.org/10.3390/ foods11050682

Academic Editor: Raul Ferrer-Gallego

Received: 4 February 2022

Accepted: 21 February 2022

Published: 25 February 2022

Publisher's Note: MDPI stays neutral with regard to jurisdictional claims in published maps and institutional affiliations.

Copyright: (C) 2022 by the authors. Licensee MDPI, Basel, Switzerland. This article is an open access article distributed under the terms and conditions of the Creative Commons Attribution (CC BY) license (https:// creativecommons.org/licenses/by/ $4.0 /)$

\begin{abstract}
The effects of lactic acid fermentation using Lactiplantibacillus plantarum 75 (L75), Leuconostoc pseudomesenteroides 56 (L56) and its combination (L56 + 75) on the quality, bioactive and volatile compounds of mango juices (MJ) from three cultivars ('Peach', 'Sabre' and 'Tommy Atkins') were investigated. Fermented and unfermented MJ were evaluated for LAB growth, physicochemical parameters, volatile compounds, antioxidants activities (DPPH, ABTS, FRAP methods), total phenolic content (TPC) and sensory properties. The unfermented juices served as a control. Twenty-four-hour fermentation was ideal for MJ based on LAB growth profiles. Generally, titratable acidity, TPC, FRAP, DPPH and ABTS scavenging activities significantly increased with fermentation by the $L 75$ strain and were highest in the L75-fermented 'Sabre' MJ, while L75-fermented 'Peach' MJ had higher ABTS activity $(p<0.05)$. In contrast, the $L 56$ strain enhanced $\beta$-carotene retention, with improved colour properties in L56-fermented 'Peach' MJ. Fermentation with L75 in 'Sabre' and 'Peach' MJ aided the synthesis of new volatile compounds (alcohols, esters, ketones and aldehydes). A PLS-DA scatter plot showed two clusters separating the 'Peach' and 'Sabre' mango juice fermented with $L 75$ from the rest. Based on the variable importance of the projection value (VIP) scores, pentadecane, 8-hexyl and butyl isobutyrate were shown as marker candidates to distinguish 'Peach' and 'Sabre' MJ fermented with L75 from the other treatments, whereas ethyl octanoate and isobutyl acetate differentiated the 'Sabre' MJ fermented with L75 from the other treatments. 'Sabre' and 'Peach' MJ fermented with L75 and L56 could provide antioxidants, meeting the recommended daily requirements for ascorbic acid and carotenoids in adults and teenagers. Hence, lactic acid fermentation of these local cultivars is a way to benefit consumers.
\end{abstract}

Keywords: antioxidants; fermentation; indigenous mango cultivars; lactic acid bacteria strain; mango juice; volatile compounds

\section{Introduction}

Lactic acid bacteria (LAB) have been employed for decades in food fermentations. The fermentation process involves the use of carbohydrates to make organic acids, most notably lactic acid, and results in metabolites that have the potential to promote health [1] In the last few decades, Lactobacilli have received increasing attention and some benefit of the recognition as probiotics that balance the gut microbiome [2]. Improved epithelial barrier integrity was reported in Lactiplantibacillus plantarum (Ltp. plantarum)-fermented tomato juice in an in vitro transepithelial electrical resistance assay [3]. Fermentation preserves foods but could also modify their organoleptic properties by producing a variety of 
flavours, aromas, textures and by eliminating antinutritive components [2]. Additionally, LAB fermentation of fruit juices is beneficial to vegans and lactose-intolerant consumers [3]. Fruit juices are well adapted to LAB fermentation due to their high sugar contents, nutrients (vitamin, mineral) and health-promoting compounds (fiber, phenolics and antioxidant) content [3]. According to Garcia et al. [4] LAB breaks down sugars in fruits and vegetables into acids, carbon dioxides and other flavour compounds, which helps modify the organoleptic properties of fermented foods, and, as an aside, improves their nutrient quality and bioaccessibility, safety and bioactivities.

Mango (Mangifera indica) fruit contains a range of antioxidants, including carotenoids, ascorbic acid, omega 3 and 6 polyunsaturated fatty acids, lutein, quercetin, mangiferin and flavonoids [5]. Mango fruit has a limited shelf life due to its highly perishable nature [6]. As a result, fermentation can be used to preserve this fruit [1]. Ltp. plantarum is the most widely used strain for lactic acid fermentation [7]. Several studies have suggested that fruit juices such as bergamot juices [8], pomegranate [9] and peaches [10] could serve as substrates for the fermentation and production of functional beverages. Furthermore, researchers have produced probiotic beverages using black cherry and barberry juices, watermelon and tomato juices using lactic acid bacteria as inoculum [11]. Another study reported the influence of brewer's yeast and Lactobacillus acidophilus on the quality of beetroot juice and carrot juice [8]. It is possible that the differences in mango cultivars and LAB strains applied in fermentation could influence the physicochemical properties, soluble sugars, organic acids, volatile compounds and functional compounds in mango juice (MJ). Therefore, when developing functional juices, it is necessary to screen for the best cultivar that could produce fruit juice with optimum physicochemical, sensory and functional properties.

Our study tested the hypothesis that cultivar variation and different LAB strains do not affect the physicochemical properties, functional compounds, antioxidant properties, sensory properties or aroma compounds after fermentation. The mango cultivars studied were 'Peach' and 'Sabre', which are popular local mango varieties widely consumed by the rural communities in South Africa, and they were compared with the commercially available cultivar 'Tommy Atkins' mangoes. Physicochemical properties, functional compounds, antioxidant properties, sensory properties and aroma volatile compounds were determined at $24 \mathrm{~h}$ of fermentation after optimising the fermentation duration and were compared to the unfermented juice. It is anticipated that the results of this study will provide food manufacturers with information about the suitability of a specific cultivar to produce fermented MJ with good nutritional properties. It is the first study in which the LAB strains Ltp. plantarum 75, and Leuconostoc pseudomesenteroides (Leu. pseudomesenteroides) 56 were tested for fermentation of local mango cultivars ('peach', 'sabre') juices singly or in combination and compared with the commercial export cultivar 'Tommy Atkins' mango juice.

\section{Materials and Methods}

\subsection{Sample Preparation}

The ripe 'Peach', 'Sabre' and 'Tommy Atkins' mango cultivars used in the study were purchased at an edible maturity stage from Tshakhuma market, Venda, Limpopo province, South Africa. All mango cultivars were disinfected by dipping in 1\% (v/v) sodium hypochlorite solution, washed thoroughly in distilled water and peeled. The juice was extracted using a Russell Hobbs $(700 \mathrm{~W})$ household blender and diluted with sterile Valpre spring water (Coca-Cola, Cape Town, South Africa) at a ratio of 1:2 (v:v, juice:water). Mango juice $(500 \mathrm{~mL})$ was pasteurized at $85^{\circ} \mathrm{C}$ in a water bath (WBE28A12E, PolyScience, Niles, IL 60714-4516, USA) for $15 \mathrm{~min}$ and cooled to room temperature $\left(25^{\circ} \mathrm{C}\right)$ before fermentation [9].

LAB strains used in the study were from the culture collections held by the University of La Réunion and QualiSud, France. Ltp. plantarum 75 (L75) and Leu. pseudomesenteroides 56 (L56) were isolated from cabbage [2]. 'Peach', 'Sabre' and 'Tommy Atkins' MJs were inoculated with LAB's cultures as described by [10], with modifications. The LABs were reactivated and propagated for $48 \mathrm{~h}$ at $30{ }^{\circ} \mathrm{C}$ in $15 \mathrm{~mL}$ of de Man, Rogosa, and Sharpe 
(MRS) broth without agitation. The resulting cells were harvested by centrifugation at $1000 \times g$ for $10 \mathrm{~min}$ and suspended in sterile water, washed twice with sterile distilled water, and suspended in the same. The turbidity of LAB cultures was determined at $720 \mathrm{~nm}$ using a spectrophotometer (SPECTRO star Nano; BMG LABTECH, Ortenberg, Germany) and bacterial population was adjusted to $0.05 \mathrm{McFarland}$ standard (5 × $\left.10^{8} \mathrm{CFU} / \mathrm{mL}\right)$ [10]. Mango juice was inoculated with LABs' cells at $1 \%$ of the total volume of juice and incubated at $30^{\circ} \mathrm{C}$ for $72 \mathrm{~h} \mathrm{[11].} \mathrm{The} \mathrm{juice} \mathrm{was} \mathrm{inoculated} \mathrm{with} \mathrm{both} \mathrm{strains} \mathrm{singly} \mathrm{and} \mathrm{in} \mathrm{combination.}$ The combined inoculum $(L 56+75)$ was developed at a ratio $(1: 1 ; v / v)$. Each fermentation was replicated five times, with unfermented juice as a control.

\subsection{Microbial Analysis and Survival of Viable LAB Cells}

The total counts of coliform, Escherichia coli, Salmonella spp., Shigella spp., mold and yeast and aerobic bacteria count were used to ascertain the safety of juices using the European commission regulation (EC 1441) [12]. Samples (1 mL) obtained from raw (0 h), un-inoculated stored at $4{ }^{\circ} \mathrm{C}(24 \mathrm{~h})$, and fermented $(24,48$ and $72 \mathrm{~h})$ MJs were homogenised in $9 \mathrm{~mL}$ of sterile saline distilled water $(0.85 \%)$, thereafter diluted serially to an appropriate population. $(100 \mu \mathrm{L})$ of MJ were plated on appropriate media MRS agar, XLD (xylose lysine deoxycholate agar), MCA (MacConkey agar), PCA (plate count agar) and PDA (potato dextrose agar) in five replicates per sample. Inoculated plates were incubated aerobically at $37^{\circ} \mathrm{C}$ for $24 \mathrm{~h}$ except PDA, at $25^{\circ} \mathrm{C}$ for $48-72 \mathrm{~h}$ and MRS at $30^{\circ} \mathrm{C}$ for $48 \mathrm{~h}$. The viability of $\mathrm{LAB}$ was monitored at $24 \mathrm{~h}$ intervals during fermentation and expressed as $\mathrm{Log} \mathrm{CFU} / \mathrm{mL}$ of juice [10].

\subsection{Evaluation of Sensory Attributes}

Sensory analysis was determined using a qualitative descriptive analysis [13], with modifications. Nine healthy trained panellists, male and female between the age of 28 and 40 years were presented with fermented and unfermented MJs. Panellists were asked to identify desired attributes before test samples were presented to them for the assessment using an unstructured bipolar scale, after which it was extrapolated into intensity scores. References samples (Table S1) were presented to panellist during a three training sessions over a period of 2 weeks to identify attributes for evaluating fermented mango juice. Mango juices were presented in coded form to the panellists in white cups placed in a white light illuminated cubicle. The following sensory attributes; bright yellow colour, fruity aroma, mango flavour, consistency (viscosity), sweet taste, bitter taste, sour taste and overall drinking quality (acceptability) were evaluated after a consensus by the panellists on the desirable attributes in MJs. A commercial fermented product (unsweetened yoghurt), glucose syrup, ripe mango juice, quinine solution, sucrose solution and citric acid solution were used as references during the training sessions for the panellists. The attributes intensity scores were assigned based on absence $(0)$, or presence of attribute; weak $=1$, moderate $=5$, and strong $=10$. The panellists rinsed their mouths with water and ate cracker biscuits in between assessments of samples.

\subsection{Determination of Physicochemical Parameters}

To determine the titratable acidity, $\mathrm{MJ}$ was titrated with $0.1 \mathrm{~N} \mathrm{NaOH}, 1 \%$, and 3-4 drops of phenolphthalein indicator were used [14]. A refractometer (Agato pocket PAL-2, Tokyo, Japan) was used to measure the total soluble solids (TSS) of the fermented and unfermented MJs [15]. Following each test, the refractometer was calibrated with distilled water. A digital pH meter (Melter-Toledo Instruments Co., Shanghai, China) was used to measure the $\mathrm{pH}$ of unfermented and fermented MJs. The $\mathrm{pH}$ meter was calibrated using buffer solutions of $\mathrm{pH} 4.0$ and 7.0.

The colour values of raw and fermented mango juice were measured using a colorimeter (CR-400 chroma Meter) calibrated with standard white tile [1] and measurements were made per sample of juice. As described in the CIE colour system, $L^{*}$ describes the lightness $($ white $=100$, black $=0), a^{*}$ refers to the intensity of redness $(+)$ and greenness $(-), b^{*}$ refers 
to the intensity of yellowness $(+)$ or blueness $(-)$, and total colour differences $(\Delta \varepsilon)$ were calculated [10].

\subsection{Ascorbic Acid Content}

The ascorbic acid (Vitamin C) was determined using 2, 6-dichloroindophenol titration method [16]. The analysis was performed in five replicates and the values were expressed as $\mathrm{mg}$ of ascorbic acid per $100 \mathrm{~mL}$ of juice.

\subsection{Total Phenol Content (TPC)}

The Folin-Ciocalteu assay method with modifications was used to determine the juice's TPC [10]. A 200- $\mu \mathrm{L}$ aliquot of a sample was mixed with $1000 \mu \mathrm{L}$ of 10 -fold diluted Folin-Ciocalteu reagent. $\mathrm{A} \mathrm{Na}_{2} \mathrm{CO}_{3}$ solution $(7.5 \%)$ was added to the sample and incubated for $2 \mathrm{~h}$. The absorbance of the sample was measured at $750 \mathrm{~nm}$ using a spectrophotometer (SPECTROstar Nano; BMG LABTECH, Ortenberg, Germany). The blank was distilled water. The concentration was calculated using a calibration curve prepared with $1 \mu \mathrm{M}$ gallic acid and the result was expressed in $\mathrm{mg} 100 \mathrm{~mL}^{-1}$ of juice.

\section{7. $\beta$-Carotene Content}

Briefly, an aliquot of mango juice $(10 \mathrm{~mL})$ was extracted using $5 \mathrm{~mL}$ of acetone: hexane (1:1) containing $0.1 \%(w / v)$ butylated hydroxytoluene (BHT) and kept in the dark overnight as described by Panfili et al. [17]. The mixture was centrifuged (Hermle Labortechnik, Germany Type $2326 \mathrm{~K}, 2010$, Wehingen, Germany) at $3420 \times \mathrm{g}$ for $15 \mathrm{~min}$ at $25^{\circ} \mathrm{C}$. The residue was rinsed thrice with $5 \mathrm{~mL}$ of the extraction solvent and centrifuged. Afterwards, the supernatants were pooled, dried in anhydrous sodium sulphate, filtered through Whatman paper (No. 1) and evaporated under a stream of nitrogen until dry. Prior to analysis, the extracts were re-dissolved in $1 \mathrm{~mL}$ of isopropyl alcohol (10\%) in n-hexane and filtered through a 0.45-m PTFE syringe filter. A Shimadzu Prominence-I LC-2030C 3D liquid chromatograph fitted with an LC-2030 autosampler and LC-2020/2040 PDA detector (Kyoto, Japan) was used for the characterisation and quantification of $\beta$-carotene. The column was a $250 \mathrm{~mm} \times 4.6 \mathrm{~mm}$ id, $5-\mu \mathrm{m}$ Shim pack GIST NH2 column. The wavelength was set at $460 \mathrm{~nm}$ at $30^{\circ} \mathrm{C}$ and the injection volume was $10 \mu \mathrm{L}$ with a flow rate of $0.6 \mathrm{~mL}$ min- 1 . $\beta$-carotene was identified by comparing retention times and absorption spectra with a pure standard. The standard curve was constructed from a range of pure $\beta$-carotene standard $\left(0-100 \mathrm{~g} \mathrm{~mL}^{-1}\right)$ at LOD (19.16) and LOQ (6.323) values and was used for quantification.

\subsection{Antioxidant Activities}

\subsubsection{2,2-Diphenyl-1-picrylhydrazyl Radial Scavenging Activity}

The antioxidants' radical-scavenging activities of 2,2-diphenyl-1-picrylhydrazyl (DPPH) radicals were assayed. The DPPH solution in methanol $(3.0 \mathrm{~mL}, 0.1 \mathrm{mM})$ was dispensed into 96-microplate wells along with various concentrations of the juice extract (0.5-15.0 mg in $150 \mathrm{~mL}$ methanol). After vigorous mixing, the samples were incubated for $30 \mathrm{~min}$ in the dark. Absorbance was measurements at $593 \mathrm{~nm}$ on a spectrophotometer (SPECTROstar Nano; BMG LABTECH GmbH, Ortenberg, Germany) [18]. The antioxidant concentration required to reduce DPPH absorbance by $50 \%$ was determined $\left(\mathrm{IC}_{50}\right)$ and the results were expressed in $\mathrm{mg} \mathrm{mL}^{-1}$ of juice.

\subsubsection{ABTS-Based Scavenging Activity}

The ABTS radical cation decolorization assay was used to assess the free radical scavenging activity. The ABTS radical cation $\left(\mathrm{ABTS}^{+}\right)$was prepared by mixing ABTS stock solution $(7 \mathrm{mM})$ with $4.9 \mathrm{mM}$ potassium persulphate in a 1:1 ratio and the mixture was stored at $25^{\circ} \mathrm{C}$ for $12-16 \mathrm{~h}$ [18]. In $1500 \mu \mathrm{L}$ of $\mathrm{ABTS}^{+}$solution, $40 \mu \mathrm{L}$ of the sample $(20,80,70$, and $100 \mu \mathrm{M})$ was added. The mixture was incubated in a 96-well microplate reader at $37^{\circ} \mathrm{C}$ for $10 \mathrm{~min}$, under dark conditions. A spectrophotometer (SPECTROstar Nano; BMG LABTECH GmbH, Ortenberg, Germany) was used to measure the decrease 
in absorbance at $593 \mathrm{~nm}$ at a concentration of $40 \mu \mathrm{M}$ of the sample (ABTS ${ }^{+}$. To calculate the $\mathrm{IC}_{50}$, the formula in Equation (1) was used, where: $\mathrm{A}=$ absorbance of control reaction; $\mathrm{B}=$ absorbance of the test sample. The results were expressed as $\mathrm{mg} \mathrm{mL}^{-1}$.

$$
(\mathrm{A}-\mathrm{B}) \times 100 / \mathrm{A}
$$

\subsubsection{Antioxidant Power}

A ferric reducing antioxidant power (FRAP) assay was conducted by combining TPTZ dissolved in $40 \mathrm{mM} \mathrm{HCl}$ with $20 \mathrm{mM}$ of $\mathrm{FeCl} 3$ in a 1:1:10 ratio with a $20 \mathrm{mM}$ acetate buffer (pH 3.6) [18]. The sample was homogenized in $80 \%$ methanol, and $20 \mu \mathrm{L}$ of the sample and $150 \mu \mathrm{L}$ of FRAP reagent were incubated for $10 \mathrm{~min}$ and the absorbance was measured at $593 \mathrm{~nm}$ using a microplate reader. Trolox solutions from 0 to $30 \mathrm{mM}$ were prepared and used as a reference standard. Results were expressed as mM TEACg-1.

\subsection{Volatile Compounds}

Volatile constituents were extracted according to the method of Hijaz et al. [19] with a few modifications. Mango juice $(10 \mathrm{~mL})$ was placed in a $50-\mathrm{mm}$ tube and $50 \mu \mathrm{L}$ of internal standard butylated hydroxytoluene $(1 \mathrm{mg} / \mathrm{mL})$ and sodium chloride $(1 \mathrm{~g})$ was added. Volatile compounds was extracted using $\mathrm{n}$-hexane $(2 \mathrm{~mL})$ and the solution was sonicated (MRC Ultrasonic cleaner, Model DC-150H, Cape Town, South Africa) at $30{ }^{\circ} \mathrm{C}$ for $30 \mathrm{~min}$, and centrifuged (Type 2326K, 2010, Hermle Labortechnik, Wehingen, Germany) at 3420×g for $10 \mathrm{~min}$ and the supernatant was separated. The residue was rinsed thrice with $\mathrm{n}$-hexane $(2 \mathrm{~mL})$ and centrifuged as above. The supernatants were pooled and dried with sodium sulphate, filtered with a white filter paper number 1 , concentrated to $250 \mu \mathrm{L}$ under a gentle stream of nitrogen, and, thereafter, stored at $5{ }^{\circ} \mathrm{C}$ before analysing using an Agilent 7890. A gas chromatograph (Agilent, Santa Clara, CA, USA) hyphenated to an Agilent 5975 C MSD with a triple-axis detector was used to analyse the volatile compounds present in non-fermented and fermented MJ. The machine was equipped with an auto sampler (Agilent Technologies GC Sampler 80). Helium was used as the carrier gas at a constant flow rate of $1 \mathrm{~mL} / \mathrm{min}$. Separation was done on a Zebron Guardian Capillary GC column (USA) with dimensions (30 $\mathrm{mm} \times 0.25 \mathrm{~mm}$ i.d and $0.25-\mu \mathrm{m}$ film thickness). The chromatographic oven program was as follows: $70{ }^{\circ} \mathrm{C}$ for $1 \mathrm{~min}$ then $3{ }^{\circ} \mathrm{C} / \mathrm{min}$ to $142{ }^{\circ} \mathrm{C}$ for $0 \mathrm{~min}$ then $5{ }^{\circ} \mathrm{C} / \mathrm{min}$ to $225^{\circ} \mathrm{C}$ for $3 \mathrm{~min}$, then $25^{\circ} \mathrm{C} / \mathrm{min}$ to $320^{\circ} \mathrm{C}$ for $3 \mathrm{~min}$; the total run time was $51.4 \mathrm{~min}$. The split less injection was carried out at a $61.6 \mathrm{kpa}$ pressure and $280^{\circ} \mathrm{C}$ inlet temperature. The mass detector was operated with an electron energy of $70 \mathrm{eV}$ in electron ionisation mode. The ion source and quadrupole temperatures were $230^{\circ} \mathrm{C}$ and $150{ }^{\circ} \mathrm{C}$, respectively, at an injection volume of $1 \mu \mathrm{L}$. Compounds were identified using the mass spectral library (NIST mass spectral library, Version 8). Alkanes were quantified using the pentadecane reference standard.

\subsection{Statistical Analysis}

Analysis was carried out in five replicates and the analysis of variance (ANOVA) was performed using statistical software (GenStat version 11.1, Hemel Hempstead, UK). Two-way ANOVA was employed to evaluate the effect of fermentation hour, LAB's strains and cultivar and the means were separated using Fischer's least significant difference at $95 \%$ significance. Results were presented as mean \pm SD. MetaboAnalyst was used to establish the correlation pattern of juice volatile compounds using the PCA, PLS-DA, heat map and clustering analysis.

\section{Results and Discussion}

\subsection{Total Soluble Solids (TSS)}

TSS is largely responsible for determining the sweetness of fruit juices. The TSS of fresh 'Peach' MJ (3.42 ${ }^{\circ}$ Brix) was higher than un-inoculated 'Sabre' (2.40 ${ }^{\circ}$ Brix) and 'Tommy Atkins' (1.76 ${ }^{\circ}$ Brix) juices (Table 1). Fermentation of 'Peach' or 'Tommy Atkins' MJs with $L 75, L 56$, or $L 56+75$ decreased the TSS compared with their unfermented counterparts. 
Meanwhile, 'Sabre' MJ fermented with $L 75$ was significantly different from the unfermented juices (at 0 and $2 \mathrm{~h}$ ) in terms of TSS, while it was not the case in $L 56$ and $L 56+75$-fermented juices. The 'Peach' MJ fermented with $L 75$ had the lowest TSS content, which represented a $50 \%$ decrease of TSS due to fermentation. Our observations agree with the decline in TSS of mango juice and sapota juice fermented with Ltp. plantarum. NCDC LP 20 for $24 \mathrm{~h}, 48 \mathrm{~h}$ and $72 \mathrm{~h}$ [13]. Additionally, the sugar depletion in Ltp. plantarum fermented cashew apple juice proceeded at a much faster rate than other LAB's during the fermentation process [20], similar to our observation. The decreasing TSS could be of health benefit to diabetic and obese patients, as it could limit the excessive intake of sugars that are abundant in juices.

Table 1. Changes in physicochemical parameters of mango juices as influenced by different lactic acid bacteria.

\begin{tabular}{|c|c|c|c|}
\hline Mango Cultivar Juice & TSS $\left({ }^{\circ}\right.$ Brix $)$ & $\mathrm{pH}$ & TA (Equivalent Lactic Acid g/100 g) \\
\hline \multicolumn{4}{|l|}{ 'peach' mango juice } \\
\hline U 0 h (Raw) & $3.42 \pm 0.27^{\mathrm{a}}$ & $4.84 \pm 0.03^{\mathrm{a}}$ & $20.00 \pm 0.02^{e}$ \\
\hline U 24 h (un-inoculated) & $3.42 \pm 0.29^{a}$ & $4.85 \pm 0.05^{\mathrm{a}}$ & $21.00 \pm 0.01^{\mathrm{e}}$ \\
\hline$L 7524 \mathrm{~h}$ & $1.72 \pm 0.08^{\mathrm{d}}$ & $3.88 \pm 0.01^{b, c}$ & $30.00 \pm 0.01^{b, c}$ \\
\hline$L 5624 \mathrm{~h}$ & $2.14 \pm 0.17^{b}$ & $3.96 \pm 0.01^{b}$ & $27.00 \pm 0.03^{c, d}$ \\
\hline$L 56+7524 \mathrm{~h}$ & $2.03 \pm 0.04^{\mathrm{c}}$ & $3.89 \pm 0.01^{b, c}$ & $29.00 \pm 0.01^{c}$ \\
\hline \multicolumn{4}{|l|}{ 'sabre' mango juice } \\
\hline U 0 h (Raw) & $2.40 \pm 0.07^{b}$ & $4.28 \pm 0.36^{\mathrm{a}}$ & $23.00 \pm 0.03^{\mathrm{d}, \mathrm{e}}$ \\
\hline U 24 h (un-inoculated) & $2.30 \pm 0.07^{b}$ & $4.18 \pm 0.11^{\mathrm{a}, \mathrm{b}}$ & $23.00 \pm 0.02^{\mathrm{d}, \mathrm{e}}$ \\
\hline$L 7524 \mathrm{~h}$ & $1.52 \pm 0.08^{d}$ & $3.66 \pm 0.03^{\mathrm{d}}$ & $36.00 \pm 0.04^{\mathrm{a}}$ \\
\hline$L 5624 \mathrm{~h}$ & $2.24 \pm 0.11^{b}$ & $3.88 \pm 0.01^{\mathrm{c}}$ & $35.00 \pm 0.04^{\mathrm{a}, \mathrm{b}}$ \\
\hline$L 56+7524 \mathrm{~h}$ & $2.26 \pm 0.11^{b}$ & $3.80 \pm 0.05^{\mathrm{c}}$ & $36.00 \pm 0.03^{a}$ \\
\hline \multicolumn{4}{|c|}{ 'Tommy Atkins' mango juice } \\
\hline U 0 h (Raw) & $1.76 \pm 0.05^{\mathrm{d}}$ & $4.12 \pm 0.01^{\mathrm{a}}$ & $23.00 \pm 0.05^{\mathrm{d}, \mathrm{e}}$ \\
\hline U 24 h (un-inoculated) & $1.76 \pm 0.05^{\mathrm{d}}$ & $4.12 \pm 0.01^{\mathrm{a}}$ & $24.00 \pm 0.02^{\mathrm{d}, \mathrm{e}}$ \\
\hline$L 7524 \mathrm{~h}$ & $0.62 \pm 0.04^{\mathrm{e}}$ & $4.01 \pm 0.01^{\mathrm{c}}$ & $28.00 \pm 0.02^{c}$ \\
\hline$L 5624 \mathrm{~h}$ & $0.72 \pm 0.08^{\mathrm{e}}$ & $4.07 \pm 0.04^{b}$ & $26.00 \pm 0.02^{\mathrm{c}, \mathrm{d}}$ \\
\hline$L 56+7524 \mathrm{~h}$ & $0.70 \pm 0.07^{\mathrm{e}}$ & $4.03 \pm 0.01^{\mathrm{c}}$ & $27.00 \pm 0.04^{\mathrm{c}, \mathrm{d}}$ \\
\hline LSD & $2.44 *$ & $0.01^{* *}$ & $0.04^{* * *}$ \\
\hline
\end{tabular}

\section{2. $p H$ and Titratable Acidity}

Overall, fermentation of juices from 'Peach', 'Sabre' and 'Tommy Atkins' mango cultivars with different $\mathrm{LAB}$ strains in combination or stand-alone resulted in a reduction in $\mathrm{pH}$ compared with their corresponding unfermented juices at 0 or $24 \mathrm{~h}$ (Table 1 ). The $\mathrm{pH}$ decreased following the pattern $(L 75>L 56+75>L 56)$ in all cultivars, ranging from 3.66 to 4.85 and was lowest in L75-fermented 'Sabre' MJ (3.66). According to Mashitoa et al. [21] the $\mathrm{pH}$ of mango puree fermented with Leu. pseudomesenteroides 56 and Ltp. plantarum 75 decreased after fermentation. In the same way, Leu. mesenteroides MPL18 and MPL39 decreased the $\mathrm{pH}$ of mango juice after fermentation [22]. The degree of lactic acid production is dependent on LAB's strains, and it could be the reason for the observed variation in $\mathrm{pH}$ in this study [1]. 
Consistently, fermentation led to an increase in titratable acidity (TA) in 'Peach' and 'Sabre' MJs fermented with L75, L56 and L56 + 75 compared with the unfermented juices, except the 'Tommy Atkins' cultivar (Table 1). The TA in fermented MJs 'Peach', 'Tommy Atkins' and 'Sabre' were in the ranges of 27-30, 26-28 and 35-36 g/100 g lactic acid, respectively. However, $L 75$-fermented juices had a significant higher TA compared to other LABs' fermented and unfermented mango cultivar juices $(p \leq 0.05)$. On the other hand, $L 56$ or $L 56+75$-fermented 'Tommy Atkins' juice showed no significant changes in the TA $(p \geq 0.05)$. Higher TA was observed in fermented 'Sabre' mango juice than in 'Peach' and 'Tommy Atkins' mango juices. A similar observation of increased TA was reported in sapota juice fermented with Ltp. plantarum NCDC LP 20 for $24 \mathrm{~h}$ [9]. Therefore, a fall in $\mathrm{pH}$ is a result of the fermentation process, where LAB metabolizes simple sugars such as sucrose, fructose, and glucose into organic acids, mainly lactic acid and carbon dioxide [2].

\subsection{Colour Properties}

Indicators of quality include colour intensity. Luminosity, brightness, colour coordinate $\left(b^{*}\right)$, and chroma $\left(c^{*}\right)$ of the yellow colour 'Peach' mango juice fermented by $L 75$ or $L 56$ were similar to that when unfermented at $0 \mathrm{~h}$ (Table 2), suggesting that there was no colour change in juice during fermentation. Similarly, the colour change $(\Delta \varepsilon)$ value was lower with LAB fermentation for $24 \mathrm{~h}$ compared with the unfermented condition. The colour difference was lowest in L56-fermented juices across mango cultivars and, furthermore, it was lowest in 'Peach' MJ (1.41). This observation could be due to increased acidity of the fermented juices which help protect against enzymatic browning. Food products with dark colours are less likely to be accepted by consumers and colour change equal to or greater than two is considered a significant colour difference in samples [10].

Table 2. Changes in colour properties of mango juices as influenced by different lactic acid bacteria.

\begin{tabular}{|c|c|c|c|c|}
\hline Mango Cultivar Juice & $L^{*}$ & $b^{*}$ & $c^{*}$ & $\Delta \varepsilon$ \\
\hline \multicolumn{5}{|l|}{ 'Peach' mango juice } \\
\hline U 0 h (Raw) & $33.62 \pm 0.36^{\mathrm{a}}$ & $18.32 \pm 0.65^{\mathrm{a}}$ & $18.40 \pm 0.65^{\mathrm{a}}$ & \\
\hline U 24 h (un-inoculated) & $31.38 \pm 0.62^{b}$ & $16.97 \pm 0.09^{b}$ & $17.01 \pm 0.11^{\mathrm{b}}$ & $6.09 \pm 0.05^{\mathrm{a}}$ \\
\hline$L 7524 \mathrm{~h}$ & $33.08 \pm 0.40^{\mathrm{a}}$ & $18.42 \pm 0.89^{a}$ & $18.63 \pm 0.85^{\mathrm{a}}$ & $1.64 \pm 0.05^{\mathrm{k}}$ \\
\hline$L 5624 \mathrm{~h}$ & $33.73 \pm 0.34^{\mathrm{a}}$ & $18.46 \pm 0.71^{\mathrm{a}}$ & $18.76 \pm 0.16^{\mathrm{a}}$ & $1.41 \pm 0.05^{1}$ \\
\hline$L 56+7524 \mathrm{~h}$ & $29.52 \pm 0.19^{b}$ & $15.51 \pm 0.45^{c}$ & $15.63 \pm 0.48^{c}$ & $3.49 \pm 0.05^{\mathrm{f}}$ \\
\hline \multicolumn{5}{|l|}{ 'Sabre' mango juice } \\
\hline U 0 h (Raw) & $33.04 \pm 0.60^{\mathrm{a}}$ & $18.25 \pm 1.12^{\mathrm{a}}$ & $18.41 \pm 1.14^{\mathrm{a}}$ & \\
\hline U $24 \mathrm{~h}$ (un-inoculated) & $30.46 \pm 0.33^{b}$ & $15.36 \pm 0.30^{\mathrm{d}}$ & $15.54 \pm 0.31^{\mathrm{c}}$ & $5.64 \pm 0.05^{b}$ \\
\hline$L 7524 \mathrm{~h}$ & $30.18 \pm 0.48^{b}$ & $14.15 \pm 0.44^{\mathrm{e}}$ & $14.32 \pm 0.47^{\mathrm{d}}$ & $4.00 \pm 0.05^{\mathrm{d}}$ \\
\hline$L 5624 \mathrm{~h}$ & $30.57 \pm 0.19^{b}$ & $15.98 \pm 0.61^{b, c}$ & $16.08 \pm 0.55^{\mathrm{b}, \mathrm{c}}$ & $3.41 \pm 0.05^{\mathrm{h}}$ \\
\hline$L 56+7524 \mathrm{~h}$ & $30.29 \pm 0.27^{b}$ & $13.52 \pm 0.88^{\mathrm{e}}$ & $13.77 \pm 0.93^{\mathrm{d}}$ & $5.16 \pm 0.05^{c}$ \\
\hline \multicolumn{5}{|c|}{ 'Tommy Atkins' mango juice } \\
\hline U 0 h (Raw) & $27.03 \pm 0.66^{c}$ & $11.12 \pm 0.14^{\mathrm{f}}$ & $9.90 \pm 0.25^{\mathrm{e}}$ & \\
\hline U 24 h (un-inoculated) & $25.02 \pm 0.13^{d}$ & $9.16 \pm 0.45^{g}$ & $9.90 \pm 0.25^{\mathrm{e}}$ & $3.54 \pm 0.05^{\mathrm{e}}$ \\
\hline$L 7524 \mathrm{~h}$ & $25.00 \pm 0.21^{\mathrm{d}}$ & $8.78 \pm 0.10^{g}$ & $9.42 \pm 0.12^{\mathrm{e}}$ & $2.65 \pm 0.05^{\mathrm{i}}$ \\
\hline$L 5624 \mathrm{~h}$ & $25.87 \pm 0.10^{\mathrm{d}}$ & $9.55 \pm 0.10^{g}$ & $10.44 \pm 0.09^{\mathrm{e}}$ & $2.25 \pm 0.05^{j}$ \\
\hline$L 56+7524 \mathrm{~h}$ & $25.82 \pm 0.07^{d}$ & $8.93 \pm 0.25 \mathrm{~g}$ & $9.58 \pm 0.27^{\mathrm{e}}$ & $3.43 \pm 0.05 \mathrm{~g}$ \\
\hline LSD & $0.19^{* *}$ & $4.65^{* * *}$ & $10.44^{* * *}$ & $0.18^{* * *}$ \\
\hline & \multicolumn{4}{|c|}{$\begin{array}{l}\text { Values with the same alphabetic letter along the column are not significantly different }(p \leq 0.05) \text {. Keys: } \mathrm{U} 0 \mathrm{~h}-\mathrm{raw} \\
\text { unfermented mango juice (control); } \mathrm{U} 24 \mathrm{~h} \text { - un-inoculated mango juice stored for } 24 \mathrm{~h} \text {; Ltp. plantarum (L75); } \\
\text { Leu. pseudomesenteroides (L56); Leu. pseudomesenteroides } 56+\text { Ltp. plantarum } 75 \text { (L56 + 75); } L^{*} \text { - degree of lightness; } \\
b^{*} \text { - degree of blueness; } c^{*} \text { — chroma; } \Delta \varepsilon \text { - colour difference; LSD-least significant difference; }{ }^{* *}=p \leq 0.005 ; \\
* * *=p \leq 0.001 \text {. }\end{array}$} \\
\hline
\end{tabular}


The observed colour change in un-inoculated ( $U 24 \mathrm{~h}$ ) mango juices from all cultivars could be due to an enzymatic browning activity [21]. However, the production of alcohols and organic acids due to the hydrolysis of free sugars by the LAB's could have possibly prevented the enzymatic browning [23] in 'Peach', 'Sabre' and 'Tommy Atkins' mango juices. In the combined culture $(L 56+75)$, significant reductions in colour attributes $\left(L^{*}, a^{*}\right.$ and chroma) were observed in 'Peach' and 'Sabre' MJs relative to the L56 and L75-fermented juices, possibly due to synergistic oxidative activities of the homo-fermentative LAB's (L75 or L56) causing the fast triggering of an enzymatic colour degradation process. In 'Tommy Atkins' juice, the $L 56+75$ had a non-significant decline in colour properties compared with $L 75$ and $L 56$ juices but significantly different from the unfermented juices $(p>0.05)$.

\subsection{Microbial Quality and LAB Growth}

The absence of growth in fermented and unfermented juices plated on XLD, MCA, PCA and PDA media (Table S2A-C) is an indication that there was no contamination in the MJs from different cultivars, therefore these samples meet the public health criteria ( $<10 \mathrm{cfu} / 100 \mathrm{~mL}$ of juice) for microbial safe juice [22]. No Salmonella, E. coli, coliforms or Shigella spp. were detected in the fermented or unfermented MJ from the selected cultivars. The total fungi count in fermented and unfermented MJ were in the range; 0.02-4.43, 0.02-0.43 and 0.01-3.46 Log CFU/mL, while the total aerobic bacterial count ranged from 1.6-9.33, 2.56-9.83 and 0.63-8.4 Log CFU/mL in 'Peach', 'Sabre' and 'Tommy Atkins' MJs, respectively. The yeast and total aerobic bacterial count was highest in L75, 24-h-fermented juices across all cultivars. With respect to cultivars, 'Tommy Atkins' had the lowest aerobic bacteria count while 'Sabre' had the highest bacterial and yeast counts in fermented MJ. According to Managa et al. [10], LAB are capable of co-existing in a consortium with acid tolerant fungi (yeast) during fermentation. A significant decrease in yeast and total aerobic bacterial count was observed in fermented MJs across cultivars $(p \leq 0.05)$, while no growth was obtained in the non-fermented samples, thus signifying a contamination-free and safe production process. No LAB growth was observed in the unfermented juice across the mango cultivars (Figure 1). After $2 \mathrm{~h}$ of fermentation, LABs had a significant increase in population and were greatest in $L 75$ samples relative to the $L 56$ and combined cultures $(L 56+75)$ in all mango juices. This corresponded to the beginning of the growth phase for the LAB cultures, while, at $24 \mathrm{~h}$, they ended the logarithmic growth phase. At $24 \mathrm{~h}$, the LAB's count ranged from 8.99 to $9.17 \log$ CFU/mL in 'Peach', 'Sabre' (8.79-9.31 log CFU/mL) and 'Tommy Atkins' (8.31-8.62 log CFU/mL). The highest population was observed in $L 75$-fermented juices ('Sabre': $9.31 \log$ CFU/mL; 'Peach': $9.17 \log$ CFU/mL and 'Tommy Atkins': $8.62 \log$ $\mathrm{CFU} / \mathrm{mL}$ ) compared with $L 56$ - and $L 56+75$-fermented MJs from different cultivars.

However, a decline in LAB population at $48 \mathrm{~h}$ before reaching a stationary phase $(p \leq 0.05)$ was observed in all cultivars with the smallest decrease in 'Peach' fermented with $L 75(0.5 \%)$. L56 +75 reached the stationary phase with a $4.78 \%$ decline at $48 \mathrm{~h}$ (8.56 Log CFU/mL) and thereafter maintained stability at $72 \mathrm{~h}$. A significant decline in the LAB population of $L 56+75$-fermented MJs from all cultivars could be due to LAB's competing for the potential use-up of nutrients and the build-up of metabolites which could constitute a toxic system. Probably the lower $\mathrm{pH}$ and increased acidity could have caused the slight reduction in the survival of LAB strains at $48 \mathrm{~h}$. Acids inhibit bacterial growth and viability by acidifying the cytoplasm, increasing energy consumption necessary for the maintenance of intracellular $\mathrm{pH}$, and inhibiting enzyme reactions [24]. A lower LAB population was observed in the 'Tommy Atkins' juices relative to other cultivars. However, significantly higher counts in all cultivar juices fermented with $L 75$ could be due to the versatile nature of Ltp. plantarum 75 in fermentation [24], while the lower sugar content in 'Tommy Atkins' MJ [25] could have made fermentation proceed slowly. Therefore, 24-h fermentation was selected and used in this study. 

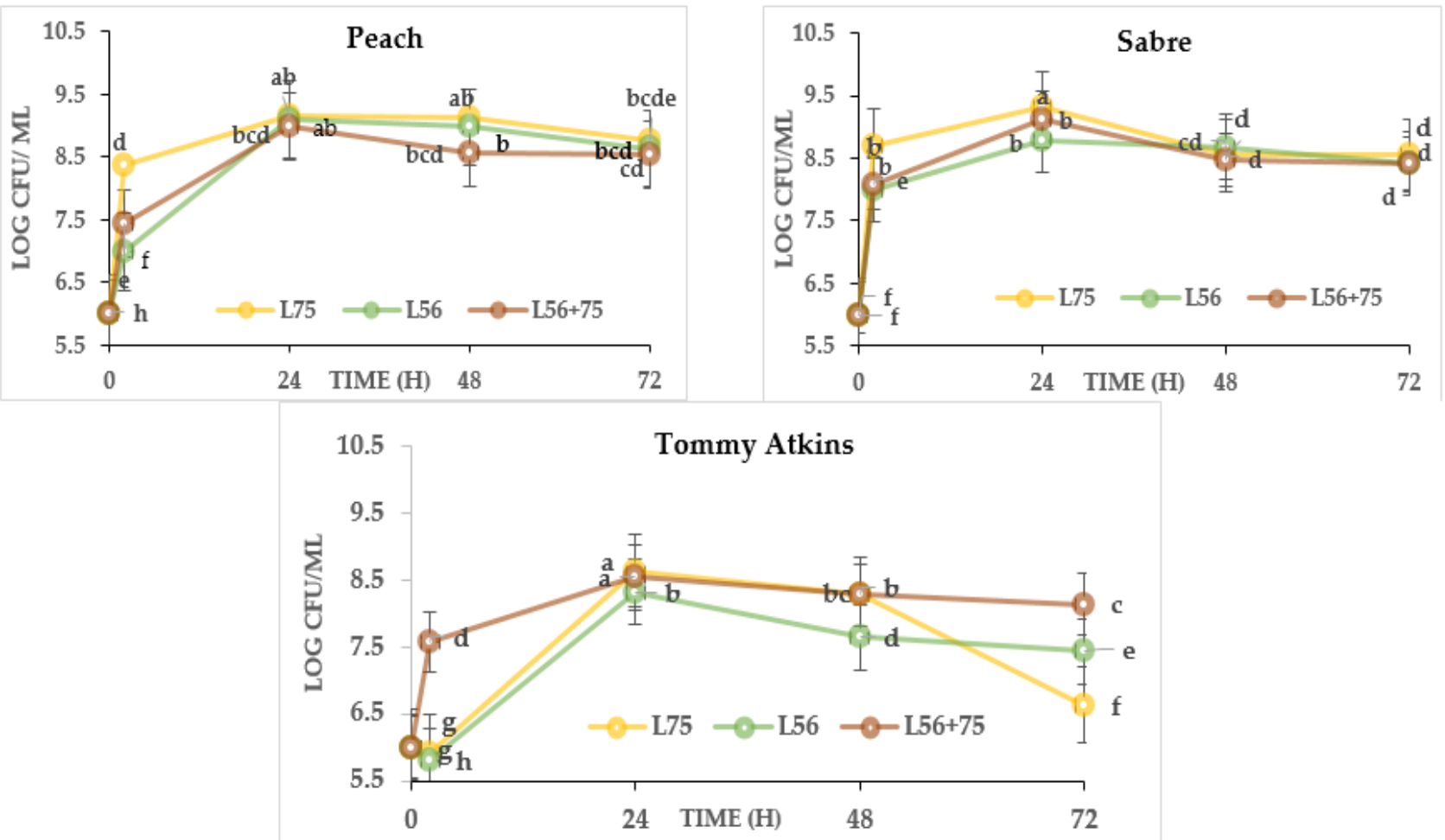

Figure 1. Population of lactic acid bacteria in fermented mango juice from different cultivars. Alphabets indicates significant difference at $p \leq 0.05$. Keys: Ltp. plantarum (L75); Leu. pseudomesenteroides (L56); Leu. pseudomesenteroides $56+$ Ltp. plantarum $75($ L56 + 75).

\subsection{Sensory Analysis}

The sensory attributes of LAB fermented and unfermented mango juices from 'Peach', 'Sabre' and 'Tommy Atkins' cultivars are presented in Figure 2. The bright yellow colour perception in mango cultivar juices was influenced by cultivar type and duration of fermentation. In 'Sabre' mango cultivar, colour perception ranged from slight yellow colour (5) in un-inoculated MJ (U 24 h) to bright yellow colour (9) in fresh juice (U 0 h), while in 'Tommy Atkins' juices, colour perception ranged from dark yellow colour (2) in L75and $L 56+75$-fermented juices to slight yellow colour in $L 56$-fermented juice. The colour perception of the 'Peach' mango cultivar ranged from weak yellow colour (4) to bright yellow (8) in the fresh juice. Fermentation and storage caused a decrease in the bright yellow colour of MJs from different cultivars, however, the $L 56$ strain aided the preservation of the yellow colour in fermented mango cultivar juices, which probably related to the inhibition of enzymatic colour change and preservation of the carotenoids. The decrease in the yellow colour perception could be due to an autoxidation process of the poly-phenolics in the juice thereby causing browning [25]. L75 strain increased the aroma perception in fermented mango juices of all cultivars. The highest aroma perception was reported by the panellists in 'Sabre' MJ fermented with L75. Consistency and sweetness were reduced in fermented mango juices of all cultivars, while bitter and sour taste increased in fermented juices. The degree of sourness was highest in 'Peach' MJ fermented with $L 56+75$, while a higher bitter taste was observed in 'Tommy Atkins' and 'Peach' MJs fermented with L56 + 75. The lower sour taste in 'Tommy Atkins' MJ could be due to the lower sugar content in this cultivar [26] thereby resulting in reduced fermentation. Panellists accepted the 'Sabre' MJ fermented with $L 75$ and sensory quality was comparable to the commercial juice. The higher acceptability of 'Sabre'-fermented juices by the panellists could be due to their mild acid taste compared to 'Peach' MJs. 

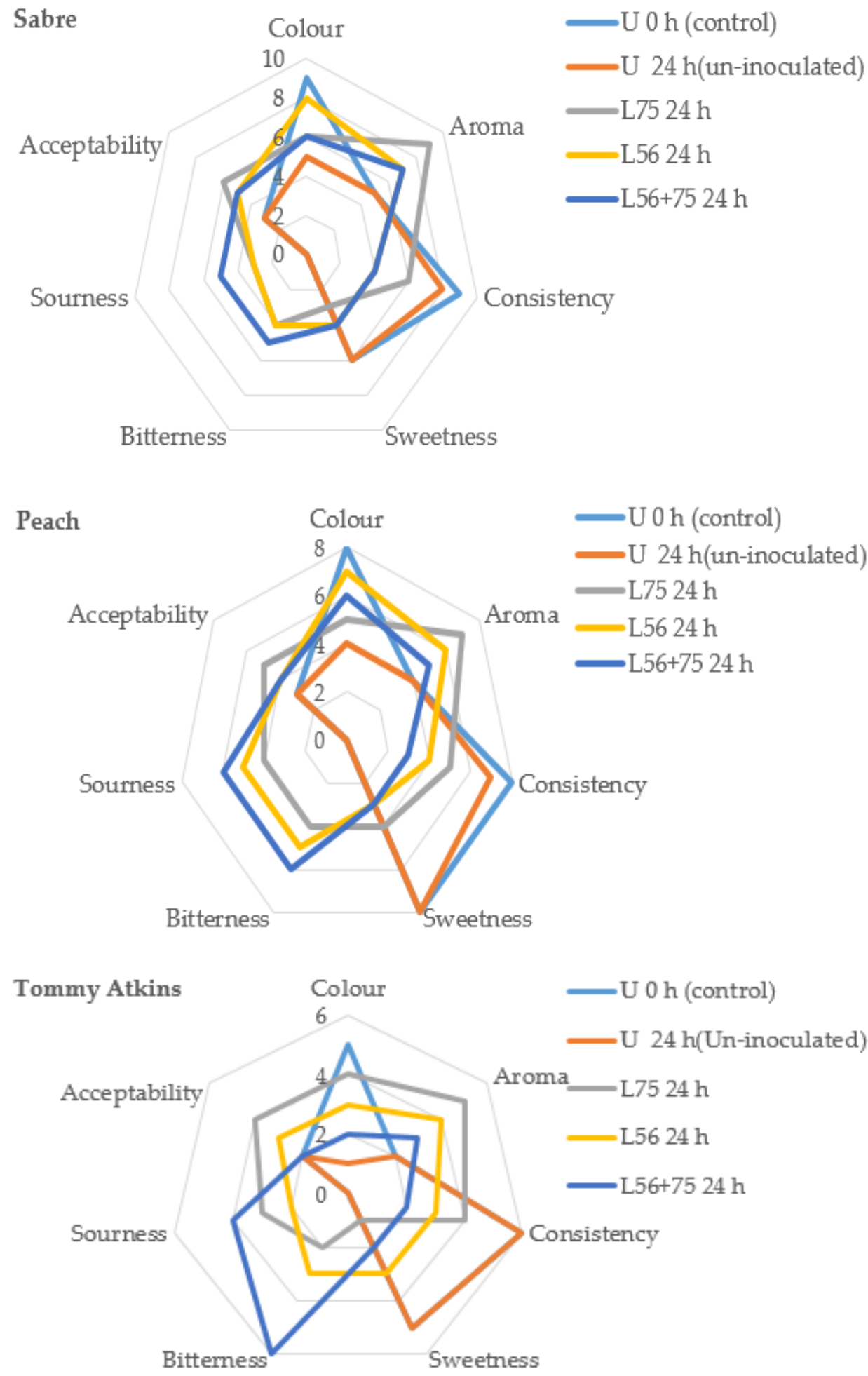

Figure 2. Sensory attributes in juice from different mango cultivars fermented by different lactic acid bacteria. Keys: U 0 h-raw unfermented mango juice (control); U 24 h-un-inoculated mango juice stored for 24 h; Ltp. plantarum (L75); Leu. psuedomesenteroides (L56); Leu. psuedomesenteroides56 + Ltp. plantarum $75($ L56 + 75).

\subsection{Chemical Constituents}

\subsubsection{Ascorbic Acid}

The 'Sabre' fresh mango juice had the highest ascorbic acid (AA) content (15 mg $100 \mathrm{~mL}^{-1}$ ) and L75-fermented 'Sabre' mango juice had the highest AA retention (11.23 mg/100 g) 
of the three mango cultivars (Table 3). However, the AA content decreased significantly at $24 \mathrm{~h}$ of fermentation. It could be that the ascorbic acid oxidase in mango juices was not completely inactivated by pasteurization, resulting in its degradation [20]. Generally, L75-fermented mango juices had the lowest reduction in AA during fermentation. A similar decrease in AA was reported in Washington navel orange juice fermented with Ltp. plantarum [27]. The observed differences in AA concentrations of unfermented juices could be attributed to the differences in cultivar types and $\mathrm{pH}$ values (Table 1). Acidic $\mathrm{pH}$ inhibits the autoxidation of AA when the redox potential changes [28]. According to this study, the effect of fermentation on AA is matrix and LAB strain specific, which could have contributed to the greater metabolism of $L 75$ and its lower $\mathrm{pH}$ level [1,27]. Women and men require 75 and $90 \mathrm{mg}$ of AA daily, respectively [29]. It is noteworthy that 2.67 and 3.2 glass $(250 \mathrm{~mL}$ ) of 'sabre' MJ fermented with $L 75$ could satisfy this daily requirement in adult women and men, respectively.

Table 3. Changes in antioxidants of mango juices as influenced by different lactic acid bacteria.

\begin{tabular}{|c|c|c|c|c|c|c|}
\hline $\begin{array}{l}\text { Juice of Different } \\
\text { Mango Cultivar }\end{array}$ & $\begin{array}{l}\text { Ascorbic Acid } \\
(\mathrm{mg} / 100 \mathrm{~g})\end{array}$ & $\begin{array}{c}\text { TPC } \\
(\mathrm{mg} / 100 \mathrm{~mL})\end{array}$ & $\begin{array}{l}\text { Beta-Carotene } \\
(\mu \mathrm{g} / \mathrm{mL})\end{array}$ & $\begin{array}{c}\text { FRAP } \\
(\mu \mathrm{M} \text { TEAC/mL) }\end{array}$ & $\begin{array}{l}\text { DPPH IC50 } \\
(\mathrm{mg} / \mathrm{mL})\end{array}$ & $\begin{array}{l}\text { ABTS IC50 } \\
(\mathrm{mg} / \mathrm{mL})\end{array}$ \\
\hline \multicolumn{7}{|l|}{ 'Peach' mango juice } \\
\hline U 0 h (control) & $10.42 \pm 0.06^{\mathrm{d}}$ & $1171.41 \pm 0.01^{\mathrm{f}}$ & $3.78 \pm 0.22^{h}$ & $354.19 \pm 0.06^{\mathrm{g}}$ & $16.33 \pm 0.01^{\mathrm{n}}$ & $10.67 \pm 0.11^{\circ}$ \\
\hline U 24 h (un-inoculated) & $5.19 \pm 0.06^{k}$ & $1051.45 \pm 0.01^{\mathrm{k}}$ & $10.85 \pm 0.83^{\mathrm{d}}$ & $254.94 \pm 0.01^{\mathrm{n}}$ & $163.52 \pm 0.02^{\mathrm{a}}$ & $28.29 \pm 0.06^{\mathrm{e}}$ \\
\hline$L 7524 \mathrm{~h}$ & $4.49 \pm 0.06^{1}$ & $1393.07 \pm 0.01^{b}$ & $17.02 \pm 1.62^{b}$ & $550.39 \pm 0.01^{b}$ & $95.92 \pm 0.01^{\mathrm{e}}$ & $14.51 \pm 0.43^{\mathrm{m}}$ \\
\hline L56 24 h & $4.13 \pm 0.01^{\mathrm{m}}$ & $1170.07 \pm 0.01^{\mathrm{h}}$ & $19.89 \pm 1.16^{\mathrm{a}}$ & $330.39 \pm 0.01^{\mathrm{h}}$ & $109.51 \pm 0.01^{\mathrm{c}}$ & $27.10 \pm 1.01^{\mathrm{f}}$ \\
\hline$L 56+7524 \mathrm{~h}$ & $3.87 \pm 0.01^{\mathrm{n}}$ & $1364.57 \pm 0.01^{c}$ & $16.33 \pm 1.95^{\mathrm{c}}$ & $461.33 \pm 0.58^{\mathrm{d}}$ & $104.15 \pm 0.01^{\mathrm{d}}$ & $22.16 \pm 0.01^{1}$ \\
\hline \multicolumn{7}{|l|}{ 'Sabre' mango juice } \\
\hline U 0 h (control) & $15.51 \pm 0.01^{\mathrm{a}}$ & $1167.03 \pm 0.01^{\mathrm{i}}$ & $0.64 \pm 0.52^{j}$ & $356.91 \pm 0.01^{\mathrm{f}}$ & $22.17 \pm 0.01^{\mathrm{m}}$ & $24.97 \pm 0.01^{j}$ \\
\hline U 24 h (un-inoculated) & $10.71 \pm 0.01^{\mathrm{c}}$ & $\underset{\mathrm{m}}{1007.08} \pm 0.01$ & $4.02 \pm 0.19 g$ & $295.06 \pm 0.01^{\mathrm{e}}$ & $56.04 \pm 0.01^{\mathrm{i}}$ & $43.27 \pm 2.17^{\mathrm{a}}$ \\
\hline$L 7524 \mathrm{~h}$ & $11.23 \pm 0.01^{\mathrm{b}}$ & $1415.71 \pm 0.01^{\mathrm{a}}$ & $4.32 \pm 0.81^{\mathrm{f}}$ & $558.28 \pm 0.01^{\mathrm{a}}$ & $44.77 \pm 0.01^{1}$ & $25.27 \pm 1.11^{\mathrm{i}}$ \\
\hline$L 5624 \mathrm{~h}$ & $9.03 \pm 0.01 \mathrm{~g}$ & $1174.64 \pm 0.01^{\mathrm{e}}$ & $8.03 \pm 1.25^{\mathrm{e}}$ & $390.37 \pm 0.06^{1}$ & $54.96 \pm 0.01^{j}$ & $37.38 \pm 6.06^{\mathrm{d}}$ \\
\hline$L 56+7524 \mathrm{~h}$ & $9.29 \pm 0.01^{\mathrm{f}}$ & $1211.33 \pm 0.01^{\mathrm{d}}$ & $0.97 \pm 0.42^{i}$ & $547.51 \pm 0.01^{\mathrm{c}}$ & $52.52 \pm 0.01^{\mathrm{k}}$ & $27.45 \pm 4.33^{g}$ \\
\hline \multicolumn{7}{|c|}{ 'Tommy Atkins' mango juice } \\
\hline U 0 h (control) & $9.68 \pm 0.01^{\mathrm{e}}$ & $923.06 \pm 0.01^{n}$ & $0.02 \pm 0.00^{\circ}$ & $297.74 \pm 0.01^{\mathrm{k}}$ & $58.52 \pm 0.01^{\mathrm{h}}$ & $13.79 \pm 0.91^{\mathrm{n}}$ \\
\hline U 24 h (un-inoculated) & $8.52 \pm 0.01^{\mathrm{h}}$ & $1089.72 \pm 0.01^{j}$ & $0.08 \pm 0.01^{\mathrm{n}}$ & $229.74 \pm 0.02^{\circ}$ & $112.53 \pm 0.01^{b}$ & $40.06 \pm 3.51^{b}$ \\
\hline$L 7524 \mathrm{~h}$ & $7.87 \pm 0.01^{\mathrm{i}}$ & $1170.84 \pm 0.01 \mathrm{~g}$ & $0.12 \pm 0.00^{\mathrm{m}}$ & $322.07 \pm 0.01^{\mathrm{i}}$ & $58.28 \pm 0.01^{\mathrm{h}}$ & $23.04 \pm 1.24^{k}$ \\
\hline$L 5624 \mathrm{~h}$ & $3.61 \pm 0.01^{\circ}$ & $1046.38 \pm 0.01^{1}$ & $0.15 \pm 0.02^{k}$ & $284.19 \pm 0.01 \mathrm{~m}$ & $62.87 \pm 0.01^{g}$ & $39.86 \pm 2.11^{c}$ \\
\hline$L 56+7524 \mathrm{~h}$ & $7.23 \pm 0.01^{j}$ & $823.31 \pm 0.01^{1}$ & $0.13 \pm 0.02^{1}$ & $298.07 \pm 0.01^{j}$ & $63.98 \pm 0.01^{\mathrm{f}}$ & $26.86 \pm 0.77^{\mathrm{i}}$ \\
\hline LSD & $3.90^{* * *}$ & $8.019 * * *$ & $0.56^{* * *}$ & $1.34^{* * *}$ & $1.27^{* * *}$ & $0.14^{* * *}$ \\
\hline \multicolumn{7}{|c|}{$\begin{array}{l}\text { Values with the same alphabetic letter along the column are not significantly different }(p \leq 0.05) \text {. Keys: } \mathrm{U} 0 \mathrm{~h}-\mathrm{raw} \\
\text { unfermented mango juice (control); } \mathrm{U} 24 \mathrm{~h}-\text { un-inoculated mango juice stored for } 24 \mathrm{~h} \text {; Ltp. plantarum (L75) } \\
\text { Leu. pseudomesenteroides (L56); Leu. pseudomesenteroides } 56+\text { Ltp. plantarum } 75 \text { (L56 }+75 \text { ); TPC-total phenolic } \\
\text { content; FRAP-ferric reducing antioxidant power; DPPH-2,2-diphenyl-1-picrylhydrazyl radial scavenging ac } \\
\text { tivity; ABTS-2,2'-azinobis-3-ethylbenzothiazoline-6-sulfonic acid; TEAC-trolox-equivalent antioxidant capacity } \\
\text { LSD-least significant difference; }{ }^{* * *}=p \leq 0.001 \text {. }\end{array}$} \\
\hline
\end{tabular}

\subsubsection{Total Phenol Content}

The TPC in un-inoculated MJs stored for $24 \mathrm{~h}$ decreased in the juices of 'Peach' and 'Sabre' mango cultivars, and the greatest decrease was obtained in 'Sabre' (13.7\%) (Table 3). This observation could be the result of enzymatic oxidation that advances the oxidation of phenolics to quinones [30]. A similar decrease in TPC was reported in strawberries [31] stored for $24 \mathrm{~h}$. Contrarily, the un-inoculated 'Tommy Atkins' juice had a significant increase in TPC $(18.05 \%)$, probably due to depolymerisation of complex glucosides in the juice. The three mango cultivar juices fermented with $L 75$ and $L 56$ showed an increase 
in TPC, with the greatest increase in 'Sabre' juice fermented with $L 75$ after $24 \mathrm{~h}$ (1415.71 $\mathrm{mg} / 100 \mathrm{~mL}$ ). In contrast, L56 + 75 increased the TPC of 'Peach', and 'Sabre' MJs by 16.48\% and $3.79 \%$, respectively, while a $10.8 \%$ decrease was observed in 'Tommy Atkins' juice. The decrease in $L 56+75$-fermented 'Tommy Atkins' juice could be due to a low sugar matrix in the juice and lower concentration of the versatile fermentative $L 75$ strains used relative to L75 singly inoculated juices.

LAB biotransformation of phenolics is matrix- and LAB-strain-dependent in mango juices, thus supporting the findings of [27] in fermented Washington navel and 'Tarocco' orange juices. Thus juices from mango cultivars ('Peach', 'Sabre' and 'Tommy Atkins') may have exhibited unique chemical characteristics that may have either facilitated or reduced the growth and enzymatic activities of LAB strains and, consequently, the amount of TPC conversion in the juices. According to Landete et al. [32] glycosylated phenolics in mulberry juice are deglycosylated by Ltp. plantarum during fermentation, thus releasing soluble conjugated or insoluble bound phenolic compounds from plant cell walls. Further, the differences in the TPC concentrations among the LAB strains-fermented MJs suggest the ability of the strains to produce more hydrolytic enzymes is highly dependent on the matrix.

\subsection{3. $\beta$-Carotene}

The $\beta$-carotene content in all three mango juices increased significantly after fermentation with $L 75$, or $L 56$ or $L 56+75$ when compared to the unfermented juices at 0 or $24 \mathrm{~h}$ (Table 3). However, fermentation with $L 56$ consistently increased the $\beta$-carotene content in all the mango cultivars juices, and the highest concentration was obtained in 'Peach' juice $\left(19.89 \mu \mathrm{g} \mathrm{mL}^{-1}\right)$ and lowest in 'Tommy Atkins' $\left(0.15 \mu \mathrm{g} \mathrm{mL}^{-1}\right)$. As suggested by Venil et al. [33] the increase in $\beta$ carotene during lactic acid bacteria fermentation could be due to an increase in the macromolecular changes that serves as a protective mechanism against oxidative stress and improves the extractability of carotenoids due to its enzymatic activity. The lower $\beta$-carotene content in $L 75$ relative to $L 56$-fermented juices from all cultivars supports the report of slight carotenoid degradation in Ltp. plantarum- and $L b$. fermentum-fermented carrot juice [34]. Lactic acid bacteria fermentation can enhance the bioavailability and release of phytochemicals in the plant matrix, such as carotenoids [34]. It is possible that the use of a combined starter culture could have increased the endogenous lipoxygenase activity and degraded the $\beta$-carotene content in juices [35]. As 9-13-year-old boys and girls requires $600 \mathrm{mcg}$ RAE of $\beta$-carotene daily, hence, 1.21 glass of $250 \mathrm{~mL}$ of L56 fermented 'Peach' mango could deliver the daily requirement of $\beta$-carotene for teenagers.

\subsection{Antioxidant Activity}

As shown in Table 3, there was a significant increase in antioxidant power in all fermented mango juices from the three cultivars after fermentation. FRAP was significantly high in $L 75$ fermented juices across cultivars and was highest in L75-fermented 'Sabre' mango juice (558.28 $\mu \mathrm{M}$ TEAC/mL) compared with the unfermented and uninoculated juices $(p<0.05)$. In contrast, L56-strain-fermented 'Peach' and 'Sabre' mango juices and L56 + 75-fermented 'Tommy Atkins' MJ had significantly lower FRAP activities relative to the fermented juices. The positive influence of $L 75$ on the antioxidant activity of the 'Peach' and 'Sabre' mango juices could be due to their hydrolytic capacity to liberate active compounds during fermentation. In addition, the antioxidant scavenging activities (DPPH) were greater in all three mango cultivar juices fermented with $L 75$ compared with other fermented juices. The highest IC50 DPPH activity was in L75-fermented 'Sabre' juice (44.7 mg/mL), while L75-fermented 'Tommy Atkins' cultivar juice was not significantly different from the control $(p>0.05)$. The antioxidant ascorbic acid is a free radical scavenger and it can scavenge DPPH radicals [36], thus, corroborating the higher AA content in L75fermented 'Sabre' juice. Additionally, lowering the $\mathrm{pH}$ increases the stability of ascorbic acid and slows its transformation to dehydroascorbic acid, which supports DPPH scavenging [37]. Moreover, its reaction is very fast as compared with that of other molecules, such 
as polyphenols, that can scavenge free radicals [25]. ABTS radical-scavenging activities are frequently used methods to evaluate antioxidant activity; free radicals become stable when they accept hydrogen ions from antioxidants, so their blue colour is lost [38]. ABTS radical-scavenging activity increased in the three mango cultivars fermented with $L 75$, with 'Peach' mango juice showing the highest $\mathrm{IC}_{50}$ level $(14.51 \mathrm{mg} / \mathrm{mL})$.

\subsection{Effects of Fermentation Process on Volatile Compounds}

A total of $171.71,169.19$ and $84.14 \mu \mathrm{g} / \mathrm{mL}$ of volatile compounds were found in the raw juice of 'Peach', 'Sabre' and 'Tommy Atkins' mango cultivars, respectively (Table 4). The total volatile compounds decreased to $76.23,96.3$ and $67.84 \mu \mathrm{g} / \mathrm{mL}$ in unfermented mango cultivars ('Peach', 'Sabre' and 'Tommy Atkins') juices, respectively, after $24 \mathrm{~h}$ of fermentation (Table 4). Fermentation with the 275 strain increased the total volatile compounds in MJs from different cultivars compared with L56 and L56 + 75 juices. 'Sabre' mango juice fermented with $L 75$ after $24 \mathrm{~h}$ had the highest volatile compounds content (27) relative to other juices, comprising alkanes (6), ketones (2), esters (14), aldehydes (4), alcohols (3) and a terpene hydrocarbon. In order to identify potential discriminant variables, multivariate data analyses, such as principal component analysis (PCA) and partial least squares-discriminant analysis (PLS-DA) were employed to reduce the complexity of the data set, as shown in Figure 3A-D. Score plots of PCA for the data set of volatile compounds are shown in Figure 3A. Based on PCA analysis of all volatile compounds, two principal components (PC) explained $57.4 \%$ of the overall variance in aroma compounds during fermentation (Figure 3B). PC1 explained 43.7\% of the variance indicating that 'Peach' and 'Sabre' mango juices fermented with L75 and 'Sabre' mango juice fermented with the combined starter $(L 56+75)$ contained high amounts of pentanal. Pentanal correlated positively on PC1 and separated the 'Peach', and 'Sabre' mango juices fermented with L75 and $L 56+75$ from other treatments.

PLS-DA scatter plot showed two clusters separating the 'Peach' and 'Sabre' MJ fermented with $L 75$ from the rest (Figure 3B). Analyses of the PLS-DA results showed that the samples tested were classified differently. Variable importance in the projection value (VIP) of the marker compounds exceeded 1.0 (Figure 3C), and the 11 marker compounds were hexadecane (1.3), amyl acetate (1.3), 2-pentanone (1.31), 2-heptanone (1.3), nonanal (1.32), methyl benzoate (1.30), butyl acetate (1.52), isobutyl acetate (1.6), ethyl octanoate (1.72); pentadecane-8-hexyl (2.13) and butyl isobutyrate (2.70). A variable's VIP score is calculated as a weighted sum of the squared correlations between the PLS-DA components and the original variable. PLS-DA in the model explains the variation in percentage terms (weights). Moreover, the volatile compounds butyl acetate (1.52), isobutyl acetate (1.6), ethyl octanoate (1.72); pentadecane-8-hexyl (2.13), butyl isobutyrate (2.70) demonstrated a VIP score $>1.5$. Based on the VIP scores, pentadecane- 8-hexyl and butyl isobutyrate could be used as markers to distinguish 'Peach' and 'Sabre' mango juices fermented with L75 from the rest of the treatments. Ethyl octanoate and isobutyl acetate separated the 'Sabre' mango juice fermented with $L 75$ from the other treatments.

The 'Sabre' MJ fermented with $L 75$ produced more volatile compounds than did other treatments (Table 4). The main volatile compounds generated during fermentation of 'Sabre' MJ by $L 75$ were pentadecane, 8-hexyl $(60.9 \mu \mathrm{g} / \mathrm{mL})$ ethyl octanoate $(30.60 \mu \mathrm{g} / \mathrm{mL})$, decane-3,7-dimethyl $(26.2 \mu \mathrm{g} / \mathrm{mL})$, butyl acetate $(22.6 \mu \mathrm{g} / \mathrm{mL}), 2,6$-di-t-butylmethylphenol acetate $(84.9 \mu \mathrm{g} / \mathrm{mL})$ ethyl butyrate $(49.02 \mu \mathrm{g} / \mathrm{mL})$ and penten-3-ol $(36.7 \mu \mathrm{g} / \mathrm{mL})$, as shown in Table 4. Using hierarchical cluster analysis, the relationship between volatile compounds and mango juice fermented with LAB cultures was uncovered. 
Table 4. Changes in volatile compounds of mango juices as influenced by different lactic acid bacteria.

\begin{tabular}{|c|c|c|c|c|c|c|c|c|c|c|c|c|c|c|c|}
\hline & 'Peach' & & & & & 'Sabre' & & & & & ‘Tomm & kins' & & & \\
\hline Volatile Compounds & U O h & U $24 \mathrm{~h}$ & $L 7524 \mathrm{~h}$ & $L 5624 \mathrm{~h}$ & $L 56+7524 \mathrm{~h}$ & U O h & U $24 \mathrm{~h}$ & $L 7524 \mathrm{~h}$ & $L 5624 \mathrm{~h}$ & $L 56+7524 \mathrm{~h}$ & $\mathrm{U} 0 \mathrm{~h}$ & U $24 \mathrm{~h}$ & $L 7524 \mathrm{~h}$ & $L 5624 \mathrm{~h}$ & $L 56+7524 \mathrm{~h}$ \\
\hline \multicolumn{16}{|l|}{ ALKANES } \\
\hline octane-2-methyl & $9.5^{\mathrm{b}}$ & $0.7^{\mathrm{d}}$ & $9.8^{\mathrm{b}}$ & $2.0^{\mathrm{d}}$ & $7.1^{\mathrm{b}, \mathrm{c}}$ & $9.5^{b}$ & $3.7^{\mathrm{c}, \mathrm{d}}$ & $18.3^{\mathrm{a}}$ & $7.7^{\mathrm{b}}$ & $1.2^{\mathrm{d}}$ & ND & $0.7^{\mathrm{d}}$ & $9.5^{b}$ & ND & ND \\
\hline Nonadecane & $2.2^{\mathrm{e}, \mathrm{f}, \mathrm{g}}$ & $1.2^{\mathrm{f}, \mathrm{g}}$ & $17.9^{\mathrm{a}}$ & $12.0^{\mathrm{b}, \mathrm{c}}$ & $6.9^{\mathrm{d}, \mathrm{e}}$ & $5.6^{\mathrm{d}, \mathrm{e}, \mathrm{f}}$ & $2.5^{\mathrm{e}, \mathrm{f}, \mathrm{g}}$ & $18.4^{\mathrm{a}}$ & $14.4^{\mathrm{a}, \mathrm{b}}$ & $2.7^{\mathrm{e}, \mathrm{f}, \mathrm{g}}$ & $2.7^{\mathrm{e}, \mathrm{f}, \mathrm{g}}$ & ND & $15.7^{\mathrm{a}, \mathrm{b}}$ & ND & $7.7^{\mathrm{c}, \mathrm{d}}$ \\
\hline hexadecane & $3.1^{\mathrm{c}}$ & $1.6^{\mathrm{c}}$ & $8.9^{\mathrm{a}, \mathrm{b}}$ & $7.7^{\mathrm{b}}$ & $8.2^{\mathrm{a}, \mathrm{b}}$ & $3.0^{\mathrm{c}}$ & $3.0^{\mathrm{c}}$ & $10.8^{\mathrm{a}}$ & $2.9^{\mathrm{c}}$ & ND & $1.3^{\mathrm{c}}$ & $1.1^{\mathrm{c}}$ & $1.6^{\mathrm{c}}$ & $1.4^{\mathrm{c}}$ & $2.3^{\mathrm{c}}$ \\
\hline pentadecane-8-hexyl & $7.8^{\mathrm{c}, \mathrm{d}}$ & $0.8^{\mathrm{d}}$ & $22.1^{\mathrm{b}}$ & $8.2^{c, d}$ & $10.9^{c}$ & $8.6^{c, d}$ & ND & $60.9^{\mathrm{a}}$ & $4.3^{\mathrm{e}}$ & $1.0^{\mathrm{e}}$ & $4.5^{\mathrm{d}, \mathrm{e}}$ & ND & $8.9^{\mathrm{c}, \mathrm{d}}$ & $1.3^{\mathrm{e}}$ & ND \\
\hline \multicolumn{16}{|l|}{ KETONES } \\
\hline 2-pentanone (fruity) & ND & ND & ND & ND & ND & ND & ND & $6.3^{\mathrm{a}}$ & ND & ND & ND & ND & ND & ND & ND \\
\hline 2-heptanone (fruity/floral) & ND & ND & ND & $\mathrm{ND}$ & ND & ND & ND & $7.6^{\mathrm{a}}$ & ND & ND & ND & ND & ND & ND & ND \\
\hline \multicolumn{16}{|l|}{ ESTERS } \\
\hline butyl isobutyrate (fruity type) & ND & ND & $10.3^{b}$ & ND & ND & $1.8^{\mathrm{d}}$ & ND & $15.5^{\mathrm{a}}$ & ND & $0.1^{\mathrm{e}, \mathrm{f}}$ & ND & ND & $1.8^{\mathrm{c}, \mathrm{d}}$ & $1.6^{\mathrm{d}, \mathrm{e}}$ & ND \\
\hline butyl acetate (banana or apple) & ND & $\mathrm{ND}$ & ND & $\mathrm{ND}$ & ND & $\mathrm{ND}$ & $1.2^{\mathrm{b}}$ & $22.6^{\mathrm{a}}$ & ND & ND & $\mathrm{ND}$ & ND & ND & $\mathrm{ND}$ & ND \\
\hline $\begin{array}{l}\text { amyl acetate (fresh-fruity, } \\
\text { reminiscent of pear, banana and } \\
\text { apple) }\end{array}$ & ND & ND & ND & ND & ND & ND & ND & $0.3^{\mathrm{a}}$ & ND & ND & ND & ND & ND & ND & ND \\
\hline methyl acetate (fruity) & ND & ND & $4.7^{\mathrm{a}}$ & ND & $0.6^{\mathrm{b}}$ & $\mathrm{ND}$ & ND & ND & ND & ND & ND & ND & ND & ND & ND \\
\hline ethyl acetate (fruity) & ND & ND & $9.5^{\mathrm{a}}$ & $5.7^{\mathrm{b}}$ & ND & $\mathrm{ND}$ & ND & ND & ND & ND & ND & ND & ND & ND & ND \\
\hline 2,6-di-t-butyl-methylphenol acetate & $56.5^{\mathrm{b}}$ & $14.0^{\mathrm{d}}$ & $83.6^{\mathrm{a}}$ & $57.4^{\mathrm{b}}$ & $30.3^{c, d}$ & $18.6^{\mathrm{d}}$ & $20.1^{\mathrm{d}}$ & $84.9^{\mathrm{a}}$ & $48.1^{b, c}$ & $22.5^{\mathrm{d}}$ & $19.1^{\mathrm{d}}$ & $18.9^{\mathrm{d}}$ & $57.4^{\mathrm{b}}$ & $34.2^{c, d}$ & $29.0^{c, d}$ \\
\hline ethyl butyrate (fruity) & $24.0^{\mathrm{c}, \mathrm{d}}$ & $16.4^{\mathrm{f}}$ & $49.0^{\mathrm{a}}$ & $43.4^{\mathrm{a}}$ & $46.7^{\mathrm{a}}$ & $31.8^{\mathrm{b}}$ & $18.0^{\mathrm{e}, \mathrm{f}}$ & $49.0^{\mathrm{a}}$ & $44.7^{\mathrm{a}}$ & $47.7^{\mathrm{a}}$ & ND & $21.7^{\mathrm{d}, \mathrm{e}, \mathrm{f}}$ & $33.4^{\mathrm{b}}$ & $22.0^{\mathrm{d}, \mathrm{e}}$ & $28.7^{\mathrm{b}, \mathrm{c}}$ \\
\hline ethyl octanoate & $3.28^{\mathrm{h}}$ & $2.6^{\mathrm{h}}$ & $21.3^{\mathrm{d}}$ & $13.6^{\mathrm{f}}$ & $13.3^{\mathrm{f}}$ & $12.5^{\mathrm{f}}$ & $5.5^{g}$ & $30.6^{\mathrm{a}}$ & $26.6^{\mathrm{b}}$ & $24.3^{c}$ & $2.6^{\mathrm{h}}$ & ND & $17.9^{\mathrm{e}}$ & $2.7^{\mathrm{h}}$ & $13.6^{\mathrm{f}}$ \\
\hline isobutyl acetate (waxy type) & $5.5^{\mathrm{d}}$ & ND & $4.8^{\mathrm{d}, \mathrm{e}}$ & $2.9^{\mathrm{e}}$ & $3.3^{\mathrm{e}}$ & $11.8^{\mathrm{c}}$ & ND & $16.9^{\mathrm{a}}$ & $14.1^{\mathrm{b}}$ & $14.1^{\mathrm{b}}$ & ND & ND & $3.9 \mathrm{~d}, \mathrm{e}$ & $2.9^{\mathrm{e}}$ & $4.0^{\mathrm{d}, \mathrm{e}}$ \\
\hline ethyl decanoate (waxy type) & $2.9^{\mathrm{c}}$ & ND & $5.2^{\mathrm{b}}$ & ND & ND & ND & ND & $8.9^{\mathrm{a}}$ & $5.2^{b}$ & $8.2^{\mathrm{a}}$ & ND & ND & $4.3^{\mathrm{b}}$ & ND & ND \\
\hline methyl benzoate (floral) & ND & ND & ND & ND & ND & ND & ND & $3.8^{\mathrm{a}}$ & ND & ND & ND & ND & ND & ND & ND \\
\hline $\begin{array}{l}\text { geranyl isovalerate (floral type, } \\
\text { green) }\end{array}$ & ND & ND & ND & ND & ND & $0.9^{\mathrm{b}}$ & ND & $1.3^{\mathrm{a}}$ & $1.0^{\mathrm{a}, \mathrm{b}}$ & $0.9^{\mathrm{b}}$ & ND & ND & ND & ND & ND \\
\hline linalyl butyrate (floral type) & ND & ND & $1.5^{\mathrm{c}}$ & ND & $0.9^{\mathrm{d}}$ & ND & ND & $2.3^{\mathrm{a}}$ & ND & $1.9^{\mathrm{b}}$ & ND & ND & $0.9^{\mathrm{d}}$ & ND & $0.7^{\mathrm{d}}$ \\
\hline \multicolumn{16}{|l|}{ ALDEHYDES } \\
\hline nonanal (rose-orange) & ND & ND & ND & ND & ND & ND & ND & $2.67^{\mathrm{a}}$ & ND & ND & ND & ND & ND & ND & ND \\
\hline e-2 hexenal (green) & $2.9^{e, f}$ & $0.9^{\mathrm{f}, \mathrm{g}}$ & $15.6^{\mathrm{a}, \mathrm{b}}$ & $1.2^{\mathrm{f}, \mathrm{g}}$ & $5.9^{\mathrm{c}, \mathrm{d}}$ & $0.9^{\mathrm{f} g \mathrm{~g}}$ & $1.1^{\mathrm{f}, \mathrm{g}}$ & $17.6^{\mathrm{a}}$ & $1.2^{\mathrm{f}, \mathrm{g}}$ & $7.2^{\mathrm{c}}$ & $1.2^{\mathrm{f}, \mathrm{g}}$ & ND & $14.2^{b}$ & $4.6^{\mathrm{d}, \mathrm{e}}$ & $3.6^{\mathrm{e}}$ \\
\hline
\end{tabular}


Table 4. Cont.

\begin{tabular}{|c|c|c|c|c|c|c|c|c|c|c|c|c|c|c|c|}
\hline & 'Peach' & & & & & 'Sabre' & & & & & 'Tomm & kins' & & & \\
\hline Volatile Compounds & U $0 \mathrm{~h}$ & U $24 \mathrm{~h}$ & $L 7524 \mathrm{~h}$ & $L 5624 \mathrm{~h}$ & $L 56+7524 \mathrm{~h}$ & U $0 \mathrm{~h}$ & $\mathrm{U} 24 \mathrm{~h}$ & $L 7524 \mathrm{~h}$ & $L 5624 \mathrm{~h}$ & $L 56+7524 \mathrm{~h}$ & U $0 \mathrm{~h}$ & U $24 \mathrm{~h}$ & $L 7524 \mathrm{~h}$ & $L 5624 \mathrm{~h}$ & $L 56+7524 \mathrm{~h}$ \\
\hline pentanal (fruity) & ND & ND & $25.9^{\mathrm{a}}$ & ND & ND & ND & ND & $25.9^{\mathrm{a}}$ & $0.04^{\mathrm{d}}$ & $20.7^{b}$ & ND & ND & $0.04^{\mathrm{d}}$ & $3.9^{\mathrm{c}}$ & $0.03^{\mathrm{d}}$ \\
\hline decanal (green) & ND & ND & $1.7^{\mathrm{b}}$ & ND & ND & ND & ND & $2.7^{\mathrm{a}}$ & ND & ND & ND & ND & ND & ND & ND \\
\hline e-3 hexanol (green) & $27.3^{\mathrm{c}, \mathrm{d}}$ & $13.9^{\mathrm{e}}$ & $33.9^{a, b}$ & $27.3^{c, d}$ & $30.3^{b, c}$ & $27.3^{c, d}$ & $14.6^{\mathrm{e}}$ & $37.3^{\mathrm{a}}$ & $29.6^{b, c}$ & $37.3^{\mathrm{a}}$ & $23.3^{\mathrm{d}}$ & $11.9^{\mathrm{e}}$ & $30.6^{b, c}$ & $27.9^{c, d}$ & $27.6^{c, d}$ \\
\hline penten-3-ol (fruity, and green) & $13.3^{\mathrm{c}, \mathrm{d}}$ & $13.4^{\mathrm{c}, \mathrm{d}}$ & $23.3^{\mathrm{b}}$ & $14.1^{\mathrm{c}, \mathrm{d}}$ & $18.0^{\mathrm{b}, \mathrm{c}}$ & $20.4^{\mathrm{b}}$ & $17.4^{b, c}$ & $36.7^{\mathrm{a}}$ & $22.7^{\mathrm{b}}$ & $22.7^{b}$ & $20.5^{\mathrm{b}}$ & $8.7^{\mathrm{d}}$ & $21.4^{\mathrm{b}}$ & $18.7^{\mathrm{b}, \mathrm{c}}$ & $20.3^{\mathrm{b}}$ \\
\hline 1-dodecanol (floral, soapy, waxy) & $\mathrm{ND}$ & ND & ND & ND & ND & $2.40^{\mathrm{b}}$ & ND & $5.8^{\mathrm{a}}$ & $2.8^{\mathrm{b}}$ & $5.7^{\mathrm{a}}$ & ND & ND & ND & ND & ND \\
\hline $\begin{array}{l}\beta \text {-myrcene (earthy, fruity, and } \\
\text { clove-like) }\end{array}$ & $4.1^{\mathrm{d}, \mathrm{e}}$ & $2.9^{\mathrm{e}}$ & $9.1^{\mathrm{c}}$ & $5.4^{\mathrm{d}, \mathrm{e}}$ & $5.4^{\mathrm{d}, \mathrm{e}}$ & $3.4^{\mathrm{d}, \mathrm{e}}$ & $1.9^{\mathrm{e}}$ & $25.4^{\mathrm{a}}$ & $5.4^{\mathrm{d}, \mathrm{e}}$ & $16.0^{\mathrm{b}}$ & $5.4^{\mathrm{e}}$ & $3.0^{\mathrm{e}}$ & $7.0^{\mathrm{c}, \mathrm{d}}$ & $5.4^{\mathrm{d}, \mathrm{e}}$ & $5.4^{\mathrm{d}, \mathrm{e}}$ \\
\hline $\begin{array}{l}\text { TOTAL } \\
\text { VOLATILE COMPOUNDS }\end{array}$ & 171.7 & 76.3 & 388.9 & 213.1 & 196.7 & 169.2 & 96.3 & 543.0 & 541.9 & 248.6 & 84.1 & 67.8 & 244.4 & 133.4 & 144.8 \\
\hline
\end{tabular}

Values with the same alphabetic letter along the column are not significantly different $(p \leq 0.05)$. Keys: $\mathrm{U} 0 \mathrm{~h}-\mathrm{raw}$ unfermented mango juice (control); $\mathrm{U} 24 \mathrm{~h}-$ un-inoculated mango juice stored for $24 \mathrm{~h}$; Ltp. plantarum (L75); Leu. pseudomesenteroides (L56); Leu. pseudomesenteroides $56+$ Ltp. plantarum 75 (L56 + 75); not detected (ND). 


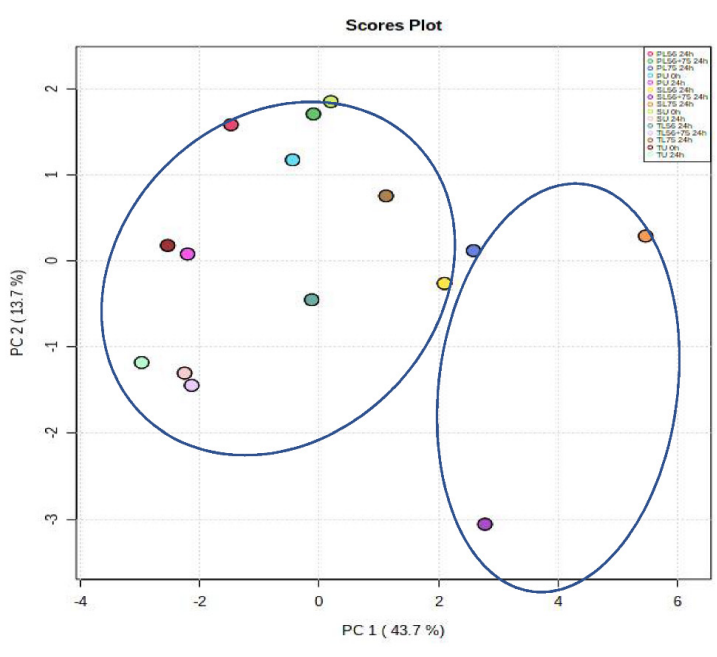

(A)

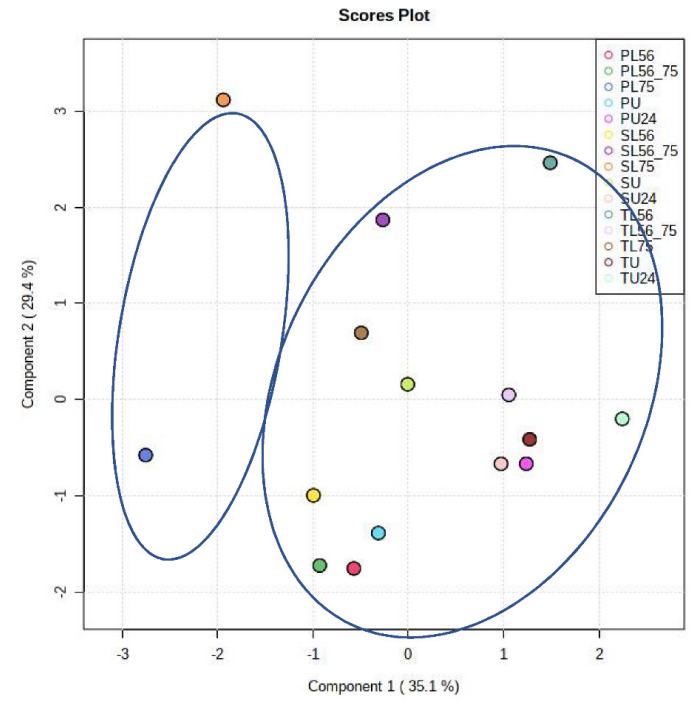

(C)

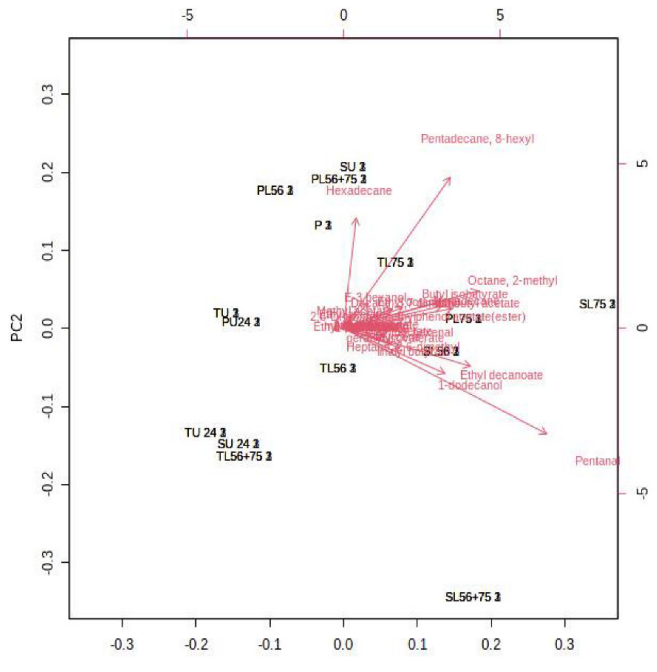

(B)

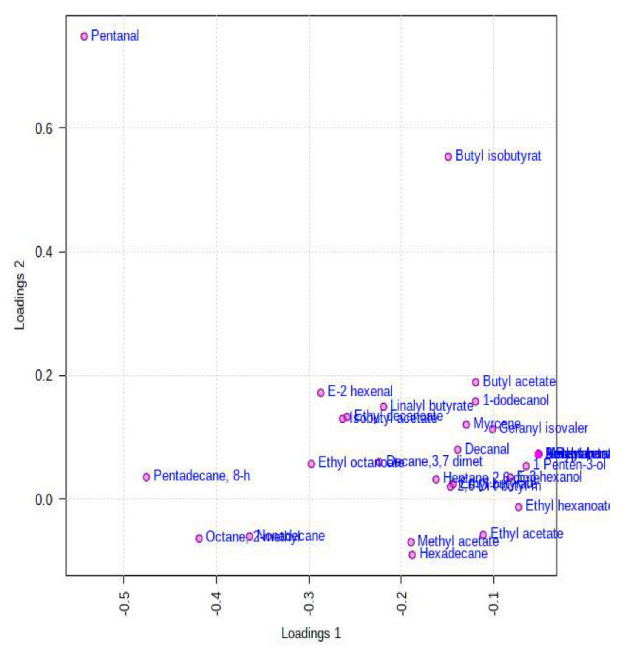

(D)

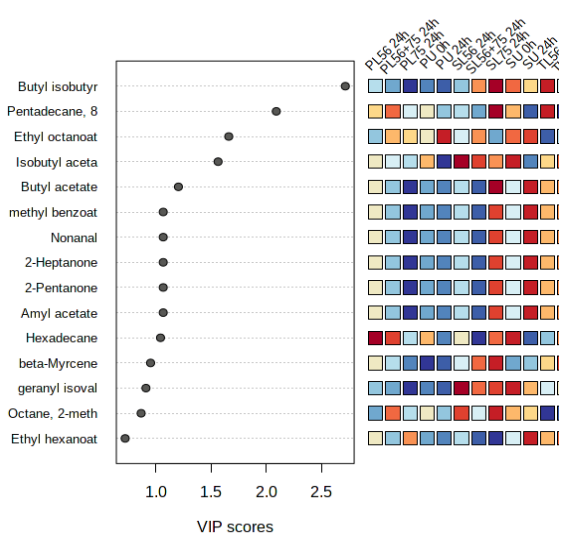

(E)

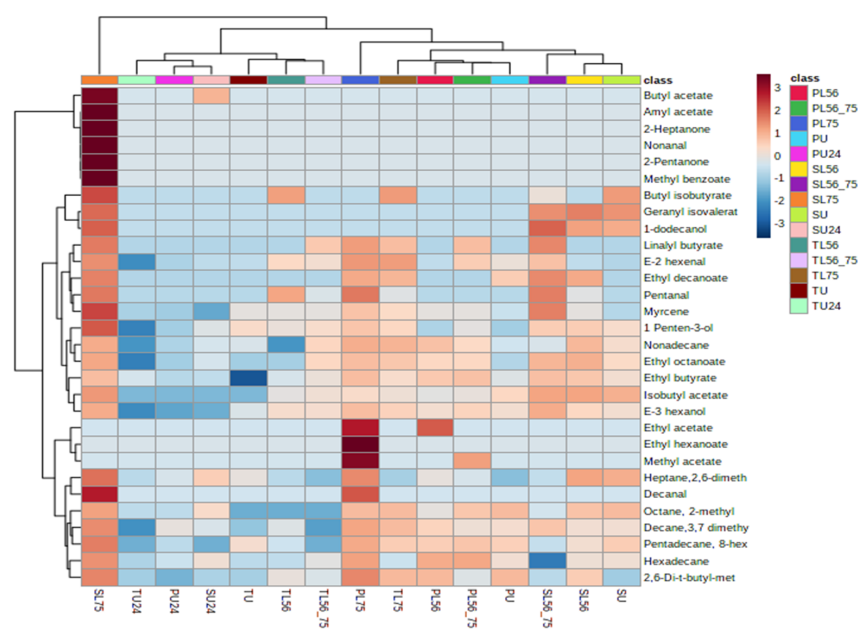

(F)

Figure 3. (A). PCA score plot and, of volatile compounds in fermented mango juices. (B). PCA loadings of volatile compounds against antioxidants and antioxidant activities of fermented mango juices from different cultivars. (C) PLS-DA score plot $(\mathrm{R} 2 \mathrm{Y}=0.66, \mathrm{R} 2 \mathrm{X}=0.70$, and Q2 $=0.51$ ) (D). PLS-DA loadings, (E) VIP results of volatile compounds of fermented mango juices. (F) Heat map 
and hierarchical clustering of volatile compounds in mango juice before and after fermentation. Keys: U 0 h-raw unfermented mango juice; U 24 h-un-inoculated mango juice stored for 24 h; L75: Lactiplantibacillus plantarum 75; Leuconostoc pseudomesenteroides 56 (L56); Leuconostoc pseudomesenteroides 56 + Lactiplantibacillus plantarum 75 (L56 + 75); P-`Peach’; S-‘Sabre’; T-`Tommy Atkins’ cultivars.

As shown in 3D, the mango juices fermented with different LAB cultures were grouped into two clusters in the heat-map. The first cluster was found in 'Sabre' MJ fermented by L75 with a higher proportion of butyl acetate, amyl acetate, 2-heptanone, nonanal, 2-pentanone, and methyl benzoate. The second cluster included all other cultivars such as 'Peach' or 'Tommy Atkins' mango juices fermented with different LAB cultures and controls. Results suggest that fermentation of 'Sabre' mango juices with $L 75$ significantly improved aroma volatile compound formation. Additionally, ethyl acetate, ethyl hexanoate and methyl acetate were only detected in 'Peach' MJ fermented with L75 at higher concentrations compared with other treatments and was not found in 'Sabre' MJ fermented with L75.

Esters positively influence the fruity flavour of the juices and enhance the sensory profile [39]. In unfermented raw 'Peach' 'Sabre', and 'Tommy Atkins' MJs, alcohols accounted for $23.65 \%, 28.19 \%$ and $52.08 \%$ of total volatile compounds, respectively. However, the alcohol recovered in the fermented MJs varied from 14.73 to $24.54 \%$ (Peach), 14.69 to $26.41 \%$ (Sabre) and $21.25 \%$ to $33.08 \%$ (Tommy Atkins). Possibly, the alcohols were used to produce esters during fermentation. Ester synthesis is largely dependent on alcohol production since fatty acyl-CoA is the major ester formed during the synthesis pathway in lactic acid fermentation [1]. Similarly, the synthesis of esters is dependent on the occurrence and activity levels of esterase [40]. Activities of the alcohol acyltransferase enzyme are involved in ester biosynthesis [41]. However, the by-products of ethanol fermentation (ethyl acetate), was found only in 'Peach' juice fermented with L75 in this investigation. The major contributor to the green taste was (E)-3 hexanol, which was found in higher concentration in 'Peach' (24.46\%), 'Sabre' (36.79\%) and 'Tommy Atkins' (31.55\%) MJs fermented by L75 and in 'Sabre' MJ fermented by L56 + 75 (36.68\%) compared with their raw counterpart. Equally, the percentage increase in 1-penten-3-ol (fruity, and green aroma) was highest in L75-fermented 'Sabre' MJ (80.23\%) followed by 'Peach' MJ (74.99\%) and was significantly different from other juices relative to the raw juice ( $\mathrm{U} 0 \mathrm{~h}$ ).

Differences in the genetic make-up of the strains, metabolism type and the type of available sugars (carbohydrate) in substrate could be the reason for the observed differences in aroma volatile compounds observed with these different LAB strains [40]. Nonanal (rose-orange flavour) was a newly produced aldehyde in 'sabre' MJ fermented with L75. Nonanal was not detected in 'Sabre' MJ fermented by L56, L56 + 75, nor in fermented 'Peach' and 'Tommy Atkins' mango juices. 'Peach' and 'Sabre' MJ fermented with L75 had the highest levels of newly formed pentanal (fruity note), followed by 'Sabre' MJ fermented with $L 56+75$. Newly formed volatile (decanal) was detected only in 'Peach' $(1.71 \mu \mathrm{g} / \mathrm{mL})$ and 'Sabre' $(2.70 \mu \mathrm{g} / \mathrm{mL})$ mango juices fermented by L75. L75 fermented 'Peach' and 'Sabre' MJs had a higher E-2 hexanal (green note) than L56, L56 + 75 or 'Tommy Atkins' MJ fermented with any of the three LAB strains. Aldehydes are typically unstable compounds that are either reduced to alcohol or oxidized to acids in food matrices [39]. Diverse enzymes in lactic acid bacteria reduces aldehydes into alcohols or oxidize them into acids. This might explain why some aldehydes and alcohols were absent at lower levels in L56 and L56 + 75-fermented mango juices. 'Sabre' MJ fermented with L75 was the most abundant in ketones (2-pentanone and 2-heptanone), which were not detected in the unfermented nor other fermented juices of 'Peach' and 'Tommy Atkins' cultivars. All alkanes (octane-2-methyl, decane-3,7-dimethyl, nonadecane, hexadecane, pentadecane 8-hexyl, heptane-2,6-dimethyl) increased significantly in 'Sabre' mango juices fermented with $L 75$ ( $p \leq 0.05)$.

Furthermore, 'Sabre' MJ fermented with $L 75$ produced higher levels of $\beta$-myrcene compared to other fermented and raw mango cultivar juices. A similar increase in $\beta$-myrcene 
was reported in Ltp. plantarum POM1- and LP09-fermented pomegranate juices [42]. Monoterpenes in MJ are either free or glycosidically conjugated [41]. Due to the low $\mathrm{pH}$ of the juices, lactic acid fermentation or enzymatic hydrolysis ( $\beta$-glucosidase) may account for the highest $(p \leq 0.05)$ levels of terpene ( $\beta$-myrcene) found in 'Sabre', 'Peach', and 'Tommy Atkins' mango juices. Acid hydrolysis changes the monoterpene aglycones and dramatically reduces their aroma, but enzymatic hydrolysis does not alter the monoterpene aglycones, and it appears to be a better method of liberating volatile monoterpenes [42] Several desirable alcohols, aldehydes, ketones, terpenes and esters are apparent in the 'Sabre' mango juice fermented with L75 (green, floral, and fruity notes).

\section{Conclusions}

Fermentation of 'Sabre', 'Peach' and 'Tommy Atkins' mango juices improves the quality its functionality. Lactic acid fermentation of mango cultivar juices is dependent on the type of strain causing the fermentation, mango cultivar and duration of fermentation. From this study, fermentation by L75, L56 and L56 + 75 for $24 \mathrm{~h}$ in mango cultivar ('Sabre', 'Peach' and 'Tommy Atkins') juices was considered suitable for quality mango juice. L75fermented 'Sabre' mango juice showed the potential to function as a probiotic due to its higher LAB survival. The L56 strain helped to retain the carotenoid content in the juices of mango cultivars and influenced the yellow colour perception. Approximately a glass of $L 56$ fermented 'Peach' mango juice could provide the daily requirement of $\beta$-carotene for teenagers. Therefore, frequent intake of 'Peach' mango juice fermented by L56 could be an ideal strategy to manage cases of night blindness in rural communities. Furthermore, the $L 75$ strain improved the physiochemical, volatile compounds, ascorbic acid, phenolic content and antioxidants activities of fermented mango cultivar juices. Fermentation of 'Sabre' mango juice by $L 75$ aids the synthesis of new alcohols, esters, ketones and aldehydes. Due to the improved physicochemical and bioactive properties, L75 fermented 'Sabre' mango juice is considered most preferred and able to deliver a functional benefit to health. The lower $\mathrm{pH}$ and TSS contents in L75-fermented juices made them suitable for people with diabetic conditions, thereby aiding the limiting of sugar intake. However, further investigations on the organic acids produced during the fermentation process should be further investigated. Hence, the fermentation of local mango cultivar 'Sabre' with L75 strain is acceptable and could be recommended to local and food processors in South Africa for better quality mango juice production.

Supplementary Materials: The following supporting information can be downloaded at: https:/ / www.mdpi.com/article/10.3390/foods11050682/s1, Table S1: Definition of attributes and references for the sensory evaluation of mango juice; Table S2A-C: Microbial counts in lactic acid bacteria fermented and unfermented 'Peach', 'Sabre' and 'Tommy Atkins' mango juices respectively.

Author Contributions: N.P.C. Masters student performed the research work and wrote the first draft of the article, S.A.A., Co supervisor responsible for the research planning, microbial analysis, fermentation, rewriting the first draft, V.E.M. performed the data validation of antioxidant assays, T.S. carried out the volatile analysis, F.R. provided the LAB cultures and guided the research. D.S. grant holder, conceptualized the research and amended the final version of the manuscript. All authors have read and agreed to the published version of the manuscript.

Funding: The authors gratefully acknowledge the SARChI Research Chair grant for Phytochemical Food Network to Improve Nutritional Quality for Consumers, supported by the NRF (National Research Foundation) grant number 98352.

Institutional Review Board Statement: Not applicable.

Informed Consent Statement: Informed consent was obtained from all subjects involved in the study.

Data Availability Statement: The datasets generated for this study are available on request to the corresponding author.

Conflicts of Interest: The authors declare no conflict of interest. 


\section{References}

1. Degrain, A.; Manhivi, V.; Remize, F.; Garcia, C.; Sivakumar, D. Effect of lactic acid fermentation on color, phenolic compounds and antioxidant activity in African nightshade. Microorganisms 2020, 8, 1324. [CrossRef] [PubMed]

2. Fessard, A.; Kapoor, A.; Patche, J.; Assemat, S.; Hoarau, M.; Bourdon, E.; Bahorun, T.; Remize, F. Lactic fermentation as an efficient tool to enhance the antioxidant activity of tropical fruit juices and teas. Microorganisms 2017, 5, 23. [CrossRef] [PubMed]

3. Wu, C.; Li, T.; Qi, J.; Jiang, T.; Xu, H.; Lei, H. Effects of lactic acid fermentation-based biotransformation on phenolic profiles, antioxidant capacity and flavor volatiles of apple juice. LWT Food Sci. Technol. 2020, 122, 109064. [CrossRef]

4. Garcia, C.; Guerin, M.; Souidi, K.; Remize, F. Lactic fermented fruit or vegetable juices: Past, present and future. Beverages 2020, 6, 8. [CrossRef]

5. Arampath, P.C.; Dekker, M. Bulk storage of mango (Mangifera indica L.) and pineapple (Ananas comosus L.) pulp: Effect of pulping and storage temperature on phytochemicals and antioxidant activity. J. Sci. Food Agric. 2019, 99, 5157-5167. [CrossRef]

6. Abbasi, N.A.; Iqbal, Z.; Maqbool, M.; Hafiz, I.A. Postharvest quality of mango (Mangifera indica L.) fruit as affected by chitosan coating. Pak. J. Bot. 2009, 41, 343-357.

7. Hashemi, S.M.B.; Jafarpour, D. Fermentation of bergamot juice with Lactobacillus plantarum strains in pure and mixed fermentations: Chemical composition, antioxidant activity and sensorial properties. LWT Food Sci. Technol. 2020, 131, 109803. [CrossRef]

8. Rakin, M.; Vukasinovic, M.; Siler-Marinkovic, S.; Maksimovic, M. Contribution of lactic acid fermentation to improved nutritive quality vegetable juices enriched with brewer's yeast autolysate. Food Chem. 2007, 100, 599-602. [CrossRef]

9. Kumar, B.V.; Sreedharamurthy, M.; Reddy, O.V.S. Probiotication of mango and sapota juices using Lactobacillus plantarum NCDC LP 20. Nutrafoods 2015, 14, 97-106. [CrossRef]

10. Managa, M.G.; Akinola, S.A.; Remize, F.; Garcia, C.; Sivakumar, D. Physicochemical parameters and bioaccessibility of lactic acid bacteria fermented chayote Leaf (Sechium edule) and pineapple (Ananas comosus) smoothies. Front. Nutr. 2021, 8, 120. [CrossRef]

11. Mousavi, Z.; Mousavi, S.; Razavi, S.; Emam-Djomeh, Z.; Kiani, H. Fermentation of pomegranate juice by probiotic lactic acid bacteria. World J. Microbiol. Biotechnol. 2011, 27, 123-128. [CrossRef]

12. European-Commission-Regulation. European Commission Regulation (EC 1441). Microbiological Criteria for Foodstuffs; European Union: Maastrick, The Netherlands, 2007.

13. Oliveira, A.d.N.; Ramos, A.M.; Minim, V.P.R.; Chaves, J.B.P. Sensory stability of whole mango juice: Influence of temperature and storage time. Food Sci. Technol. 2012, 32, 819-825. [CrossRef]

14. Reddy, L.V.; Min, J.-H.; Wee, Y.-J. Production of probiotic mango juice by fermentation of lactic acid bacteria. Microbiol. Biotechnol. Lett. 2015, 43, 120-125. [CrossRef]

15. Al-Sahlany, S.T.; Niamah, A.K. Bacterial viability, antioxidant stability, antimutagenicity and sensory properties of onion types fermentation by using probiotic starter during storage. Nutr. Food Sci. 2022; in press. [CrossRef]

16. Official-Methods-of-Analysis. Vitamin C (reduced ascorbic acid) in ready-to-feed milk-based infant formula. In $A O A C O f f i c i a l$ Method 985.33; AOAC Official Method: Rockville, MD, USA, 2000.

17. Panfili, G.; Fratianni, A.; Irano, M. Improved normal-phase high-performance liquid chromatography procedure for the determination of carotenoids in cereals. J. Agric. Food Chem. 2004, 52, 6373-6377. [CrossRef]

18. Seke, F.; Manhivi, V.E.; Shoko, T.; Slabbert, R.M.; Sultanbawa, Y.; Sivakumar, D. Extraction optimisation, hydrolysis, antioxidant properties and bioaccessibility of phenolic compounds in Natal plum fruit (Carissa macrocarpa). Food Biosci. 2021, $44,101425$. [CrossRef]

19. Hijaz, F.; Nehela, Y.; Killiny, N. Possible role of plant volatiles in tolerance against huanglongbing in citrus. Plant Signal. Behav. 2016, 11, e1138193. [CrossRef]

20. Kaprasob, R.; Kerdchoechuen, O.; Laohakunjit, N.; Sarkar, D.; Shetty, K. Fermentation-based biotransformation of bioactive phenolics and volatile compounds from cashew apple juice by select lactic acid bacteria. Process Biochem. 2017, 59, 141-149. [CrossRef]

21. Mashitoa, F.M.; Akinola, S.A.; Manhevi, V.E.; Garcia, C.; Remize, F.; Slabbert, R.; Sivakumar, D. Influence of Fermentation of Pasteurised Papaya Puree with Different Lactic Acid Bacterial Strains on Quality and bioaccessibility of phenolic compounds during in vitro digestion. Foods 2021, 10, 962. [CrossRef]

22. Liao, X.-Y.; Guo, L.-Q.; Ye, Z.-W.; Qiu, L.-Y.; Gu, F.-W.; Lin, J.-F. Use of autochthonous lactic acid bacteria starters to ferment mango juice for promoting its probiotic roles. Prep. Biochem. Biotechnol. 2016, 46, 399-405. [CrossRef]

23. Gong, Y.; Wang, Q.; Ma, S.; Ma, Y.; Meng, Q.; Zhang, Z.; Shi, J. Short-time water immersion inhibits browning of fresh-cut potato by enhancing antioxidant capability and tyrosine scavenging. J. Food Process. Preserv. 2019, 43, e14168. [CrossRef]

24. Shabala, L.; McMeekin, T.; Budde, B.B.; Siegumfeldt, H. Listeria innocua and Lactobacillus delbrueckii subsp. bulgaricus employ different strategies to cope with acid stress. Int. J. Food Microbiol. 2006, 110, 1-7. [CrossRef] [PubMed]

25. Zhang, D.; Hamauzu, Y. Phenolic compounds, ascorbic acid, carotenoids and antioxidant properties of green, red and yellow bell peppers. J. Food Agric. Environ. 2004, 1, 22-27. [CrossRef]

26. Abourayya, M.; Kassim, N.; El-Sheikh, M.; Rakha, A. Fruit physical and chemical characteristics at maturity stage of Tommy Atkins, Keitt and Kent mango cultivars grown under Nubariya conditions. J. Am. Sci. 2011, 7, 228-233. 
27. Multari, S.; Carafa, I.; Barp, L.; Caruso, M.; Licciardello, C.; Larcher, R.; Tuohy, K.; Martens, S. Effects of Lactobacillus spp. on the phytochemical composition of juices from two varieties of Citrus sinensis L. Osbeck: 'Tarocco' and 'Washington navel'. LWT Food Sci. Technol. 2020, 125, 109205. [CrossRef]

28. Filannino, P.; Di Cagno, R.; Gobbetti, M. Metabolic and functional paths of lactic acid bacteria in plant foods: Get out of the labyrinth. Curr. Opin. Biotechnol. 2018, 49, 64-72. [CrossRef]

29. Monsen, E.R. Dietary reference intakes for the antioxidant nutrients: Vitamin C, vitamin E, selenium, and carotenoids. J. Am. Diet. Assoc. 2000, 100, 637-640. [CrossRef]

30. Huang, X.-M.; Wang, H.-C.; Yuan, W.-Q.; Lu, J.-M.; Yin, J.-H.; Luo, S.; Huang, H.-B. A study of rapid senescence of detached litchi: Roles of water loss and calcium. Postharvest Biol. Technol. 2005, 36, 177-189. [CrossRef]

31. Piljac-Žegarac, J.; Šamec, D. Antioxidant stability of small fruits in postharvest storage at room and refrigerator temperatures. Food Res. Int. 2011, 44, 345-350. [CrossRef]

32. Landete, J.M.; Curiel, J.A.; Rodríguez, H.; de las Rivas, B.; Muñoz, R. Aryl glycosidases from Lactobacillus plantarum increase antioxidant activity of phenolic compounds. J. Funct. Foods 2014, 7, 322-329. [CrossRef]

33. Venil, C.K.; Dufossé, L.; Renuka Devi, P. Bacterial pigments: Sustainable compounds with market potential for pharma and food industry. Front. Sustain. Food Syst. 2020, 4, 100. [CrossRef]

34. Mapelli-Brahm, P.; Barba, F.J.; Remize, F.; Garcia, C.; Fessard, A.; Khaneghah, A.M.; Sant'Ana, A.S.; Lorenzo, J.M.; Montesano, D.; Meléndez-Martínez, A.J. The impact of fermentation processes on the production, retention and bioavailability of carotenoids: An overview. Trends Food Sci. Technol. 2020, 99, 389-401. [CrossRef]

35. Antognoni, F.; Mandrioli, R.; Potente, G.; Saa, D.L.T.; Gianotti, A. Changes in carotenoids, phenolic acids and antioxidant capacity in bread wheat doughs fermented with different lactic acid bacteria strains. Food Chem. 2019, 292, 211-216. [CrossRef] [PubMed]

36. Schlesier, K.; Harwat, M.; Böhm, V.; Bitsch, R. Assessment of antioxidant activity by using different in vitro methods. Free Radic. Res. 2002, 36, 177-187. [CrossRef]

37. Scalzo, R.L. Organic acids influence on DPPH scavenging by ascorbic acid. Food Chem. 2008, 107, 40-43. [CrossRef]

38. Karadag, A.; Ozcelik, B.; Saner, S. Review of methods to determine antioxidant capacities. Food Anal. Methods 2009, 2, 41-60. [CrossRef]

39. Di Cagno, R.; Surico, R.F.; Paradiso, A.; De Angelis, M.; Salmon, J.-C.; Buchin, S.; De Gara, L.; Gobbetti, M. Effect of autochthonous lactic acid bacteria starters on health-promoting and sensory properties of tomato juices. Int. J. Food Microbiol. 2009, 128, 473-483. [CrossRef]

40. Smit, G.; Smit, B.A.; Engels, W.J. Flavour formation by lactic acid bacteria and biochemical flavour profiling of cheese products. FEMS Microbiol. Rev. 2005, 29, 591-610. [CrossRef]

41. Tiwari, S.; Kate, A.; Mohapatra, D.; Tripathi, M.K.; Ray, H.; Akuli, A.; Ghosh, A.; Modhera, B. Volatile organic compounds (VOCs): Biomarkers for quality management of horticultural commodities during storage through e-sensing. Trends Food Sci. Technol. 2020, 106, 417-433. [CrossRef]

42. Di Cagno, R.; Filannino, P.; Gobbetti, M. Lactic acid fermentation drives the optimal volatile flavor-aroma profile of pomegranate juice. Int. J. Food Microbiol. 2017, 248, 56-62. [CrossRef] 